\title{
23 Ekim 2011 Van (Doğu Anadolu) Depremi’nin (Mw=7.1) Sismotektonik Özellikleri
}

\author{
Seismotectonic Characteristics of the 23 October 2011 Van (Eastern \\ Anatolia) Earthquake (Mw=7.1)
}

\section{MURAT UTKUCU1', EMRAH BUDAKOĞLU1, HILAL YALÇIN', HATICE DURMUŞ', LEVENT GÜLEN ${ }^{1}$, ERCAN IŞIK ${ }^{2}$}

'Sakarya Üniversitesi, Mühendislik Fakültesi, Jeofizik Mühendisliği Bölümü, 54187, SerdivanSAKARYA

${ }^{1}$ Bitlis Eren Üniversitesi, Mühendislik-Mimarlık Fakültesi, İnsaat Mühendisliği Bölümü, 13000, MerkezBiTLIS

Geliș (received) : 05 Ocak (january) 2014

Kabul (accepted) : 07 Temmuz (July) 2014

\section{öz}

23 Ekim 2011 Van depreminin geniș bant uzak-alan cisim dalga șekillerinin sonlu-fay modellemesi deprem kırılmasının ters faylanma olduğunu ve tek tarafı olarak GB'ya yayıldığını göstermiștir. Kırılma 5 km altında kısıtlı kalmıș, yaklașı 5.5 m en büyük kayma ile $25 \times 16$ km’lik bir fay alanını örtmüș ve yaklașık 11 sn sürmüștür. Sonlu-fay modeli için hesaplanan sismik moment $4.6 \times 10^{19} \mathrm{Nm}(\mathrm{Mw}=7.1)$ olup çoğunluğu kırılma bașlangıcından sonraki 5-9 sn zaman aralığında serbestlenmiștir. Sonlu-fay analizi en büyük kayma alanı için 3 sn'lik bir yükselim zamanı önermektedir.

2011 Van depreminin 3 büyük artçı depreminin uzak-alan nokta kaynak modellemesi bu artçı depremlerin hem ters hem de doğrultu atımlı faylanma mekanizmalarına sahip olduğunu göstermiș, 9 Kasım 2011 artçı depreminin ana șoktan farklı bir fay üzerinde meydana geldiğini doğrulamıștır. 2011 Van depremi artçı depremlerini içererek ve içermeden yapılan Van Gölü bölgesindeki deprem odak mekanizmalarının gerilme tensör analizleri bölgede gerilme rejiminin doğrultu-atımlı olduğunu ve sıkıșma gerilmesi ekseninin yaklașık K-G doğrultusunda uzandığını belirtmiștir.

2011 Van depremi Doğu Anadolu'da aletsel dönemde hemen hemen tamamıyla ters faylanmalı olarak meydana gelmiș ilk büyük deprem olup bölgede yaygın olarak gözlenen doğrultu atımlı faylanmaların yanısıra ters faylanmalarında meydana gelebileceğini kanıtlamıștır.

Anahtar Kelimeler: 23 Ekim 2011 Van depremi, Doğu Anadolu, Telesismik ters çözüm, Sonlu-fay modellemesi

\begin{abstract}
The finite-fault modelling of the 23 October 2011 Van earthquake using teleseismic broadband body waveforms has shown that the earthquake occured as a result of reverse faulting and its rupture propogated unilaterally toward $S W$. The rupture confined to below the depth of $5 \mathrm{~km}$, covering a fault area of $25 \mathrm{~km}$ by $16 \mathrm{~km}$ with a peak slip of about $5.5 \mathrm{~m}$ and it lasted for about $11 \mathrm{~s}$. The total seismic moment calculated for the finite-fault model is $4.6 \times 10^{19}$ $\mathrm{Nm}(\mathrm{Mw}=7.1)$, most of which was released in between 5-9 s after the rupture initiation. The finite-fault analysis suggests a rise-time of $3 \mathrm{~s}$ for the largest slip area.
\end{abstract}

Teleseismic point source modelling of the three large aftershocks suggests that these aftershocks have both reverse and strike-slip source mechanisms and it also confirmed that the 9 November 2011 aftershock occurred on a different fault. Stress tensor inversion analysis using earthquake focal mechanisms in the Lake Van area with and without the 2011 Van earthquake aftershocks suggested that the stress regime in the area is mainly strike-slip with compression stress axis extending nearly in NS direction. The 2011 Van earthquake is the first large earthquake

M.Utkucu

e-posta: mutkucu@sakarya.edu.tr 
with almost pure reverse faulting to occur in Eastern Anatolia during the instrumental period suggesting that reverse faulting can also occur along with dominantly observed strike-slip faulting in the region.

Keywords: The 23 October 2011 Van earthquake, Eastern Anatolia, Teleseismic inversion, Finite-fault modelling

\section{Giriș}

23 Ekim 2011 Van depremi Doğu Anadolu Bloğu'nda (DAB), Van Gölü Havzası içinde meydana gelmiștir (Șekil 1 ve 2). DAB'nun ana sismotektonik özellikleri güneydeki Arap Levhasının kuzeybatı yönündeki göreceli hareketi ile Bitlis Bindirme Zonu (BBZ) boyunca Anadolu levhasına çarpması sonucu gelișmiștir (Șekil 1). Batıda, Anadolu Levhası Kuzey ve Doğu Anadolu Fay Zonları boyunca batıya hareket etmektedir. Yakın geçmișteki araștırmalar günümüzde DAB içinde esas tektonik rejimin kıtasal çarpıșma kaynaklı sıkıșma olduğunu ve bu deformasonun genel olarak doğrultu atımlı faylarla KD'da Kafkasya'ya kadar iletildiğini göstermiștir (Sandvol vd., 2003; Șengör vd.,, 2003; Dhont ve Chorowicz, 2006; Djamour vd., 2011). GPS çaıșmalarından elde edilen kabuksal hız alanı bu görüșü doğrulamaktadır (McClusky vd., 2000; Vernant vd., 2004; Reilinger vd.,, 2006; Dhont ve Chorowicz 2006). GPS çalıșmaları, BBZ güneyinde Arap levhasının hız ve hareket doğrultusunun sirasiyla $18 \pm 2 \mathrm{~mm} / \mathrm{yr}$ ve $\mathrm{K} 24^{\circ} \pm 5^{\circ} \mathrm{D}$ olduğunu ve bu hareketin çoğunlukla DAB'na iletildiğini göstermektedir. Bu tektonik özellikleri deprem kaynak mekanizmaları destekler niteliktedir (Șekil 1) (Toksöz vd., 1978; Stewart ve Kanamori, 1982; Jackson ve McKenzie 1984; Pınar 1995; Eyidoğan vd., 1991).

DAB içinde uzanan bir çok KB-GD doğrultulu sağ yanal ve KD-GB doğrultulu sol yanal doğrultu atımlı faylar Kafkasya bindirmelerine deformasyon iletimini sağlamaktadırlar (Barka ve Kadinsky-Cade 1988; Jackson 1992; McClusky vd., 2000; Koçyiğit vd., 2001). Bu faylardan bir kaçı BBZ'nin hemen kuzeyinde yer alan Van Gölü havzası içinde uzanmaktadır (Șekil 2). Bunlar, sağ yanal Tutak, Çaldıran, Erciș, Karayazı, Hasan Timur, Bitlis, Bahçesaray fay zonları ve sol-yanal Malazgirt, Ahlat ve Süphan fay zonlarıdır. Bu faylara ilave olarak Van Gölü'nün doğusunda ikincil önemde doğrultu atımlı faylar da yer almaktadır (Șekil 2) (Lahn 1946; Tașman 1946; Özkaymak 2003; Koçyiğit vd., 2011). Bunlar sağ yanal Edremit, Kalecik ve Alabayır fayları ile sol yanal Çakırbey fayı șeklinde sıralanabilir. Bunların yanı sıra 2011Van depremi ile dirilikleri ve büyük deprem üretme potansiyelleri kanıtlanan ters faylar Van Gölü havzası içinde uzanmaktadır. Bunlar Muș bindirmesi, Van fayı, Gürpınar fayı, ve Van Gölü havzasını sınırlayan Kuzey (KSF) ve Güney (GSF) Sınır faylarıdır (Șengör vd., 1985; Wong ve Degens, 1978; Degens vd., 1978; Litt vd., 2009; Akyüz vd., 2011; JMO. 2011; Emre vd., 2011; Koçyiğit vd., 2011) .

Bu çalıșmada 2011 Van depreminin sismotektonik özellikleri irdelenecektir. Bölgenin depremselliğinden kısaca bahsedildikten ve 2011 Van depremi tanıtılıktan sonra öncelikle 2011 Van depremi için daha önceki bir çalıșmada verilen sonlu-fay telesismik (uzak-alan) kırılma modeli, kırımanın uzay-zaman evrimi bağlamında analiz edilecek ve $M w \geq 5$. 6 olan 3 artçı depremin uzak-alan nokta kaynak modellemesi yapılacaktır. Daha sonra Van Gölü havzası içindeki bölgesel gerilme rejimi mevcut deprem odak mekanizmalarından belirlenmeye çalıșılarak elde edilen tüm sonuçlar sismotektonik açıdan irdelenecektir.

\section{VAN GÖLÜ HAVZASININ DEPREMSELLIĞi}

Türkiye'nin ana tektonik unsurlarını belirleyen ilk çalıșmalarda bile Van Gölü Havzası birinci derece deprem bölgesi olarak sınıflandırılmıștır (Lahn, 1949). Aletsel dönemde (1900 sonrası), 2011 Van depremi dıșında bölgeyi önemli ölçüde etkileyen büyüklüğü $M_{s} \geq 7.0$ olan iki depremin (1903 Malazgirt $\left(M_{\mathrm{s}}=7.0\right)$, ve 1976 Çaldıran $\left(M_{\mathrm{s}}=7.3\right)$ depremleri) meydana gelmesi ve 1900 öncesi meydana gelen ve büyüklüğü $M_{\mathrm{s}} \approx 7.0$ olan beș depremin (1646 ve 1715 Van, 


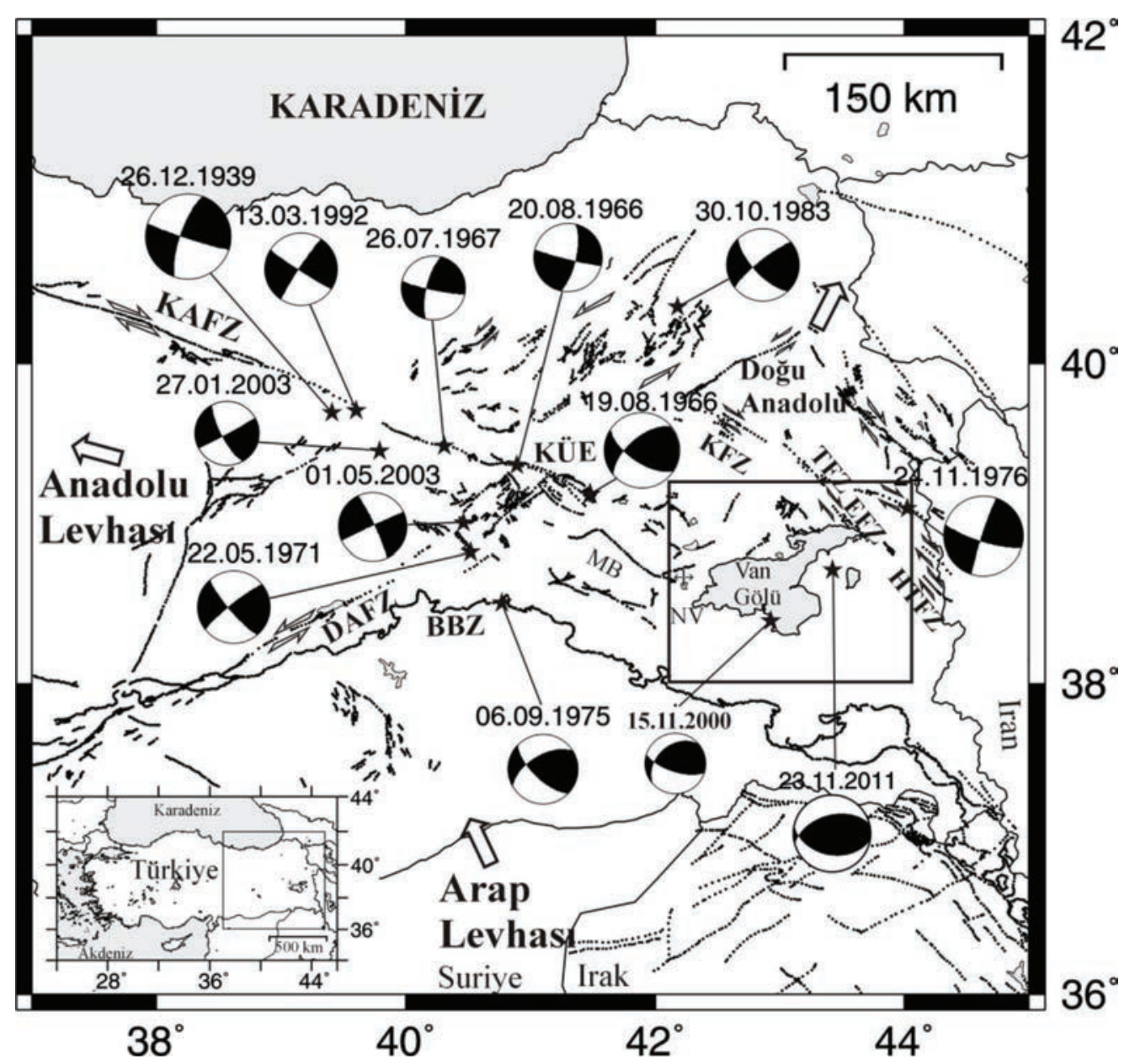

Șekil 1. Doğu Anadolu'nun belli bașlı tektonik unsurları, aletsel dönemdeki odak mekanizmaları bilinen MS $\geq 6.0$ depremler (siyah yıldızlar) (McKenzie (1972), Toksöz vd.,. (1978), Taymaz vd., (1991), Șaroğlu vd., (1992) ve Pınar (1995)'den derlenmiștir. KAFZ Kuzey Anadolu Fay Zonu, DAFZ Doğu Anadolu Fay Zonu, BBZ Bitlis Bindirme Zonu, MB Muș Bindirmesi, KÜE Karlıova Üçlü Eklemi, KFZ Karayazı Anadolu Fay Zonu, TFZ Tutak Anadolu Fay Zonu, EFZ Erciș Anadolu Fay Zonu, HTFZ Hasan Timur Anadolu Fay Zonu. Büyük dikdörtgen Șekil 2 ve 3'de gösterilen harita alanlarını çevrelemektedir.

Fig. 1. Major tectonic elements of Eastern Anatolia along with the instrumental period $M_{s} \geq 6.0$ earthquakes (black stars) and known focal mechanisms (compiled from McKenzie (1972), Toksöz vd., (1978), Taymaz vd., (1991), Șaroğlu vd., (1992) and Pınar (1995)). KAFZ North Anatolian Fault Zone, DAFZ East Anatolian Fault Zone, BBZ Bitlis Thrust Zone, MB Muș Thrust, KÜE Karlıova Triple Junction, KFZ Karayazı Fault Zone, TFZ Tutak Fault Zone, EFZ Erciș Fault Zone, HTFZ Hasan Timur Fault Zone. Large rectangle encloses the map areas shown in Figs. 2 and 3.

1670 ve 1705 Bitlis ve 1696 Çaldıran depremleri), tarihsel dönem deprem kayıtlarında yer alması bölge içindeki deprem tehlikesinin en önemli kanıtlarıdır (Tablo 1; Șekil 2) (Ambraseys 1988, 1989, 2011; Ambraseys ve Finkel 1995; Sinclair 1999; Kalafat vd., 2007; Albini vd., 2012). Van Gölü havzasında 1500 ile 1860 yılları arasında sadece zarar verici depremlerin, 1860 yılı sonrasında da büyüklüğü $M \geq 5.0$ olan bilinen tüm depremler Tablo1'de verilmiștir.
Tablo 1'den görüleceği üzere Van Gölü ve yakın civarında aletsel dönemde büyüklükleri $5.0 \leq \mathrm{M} \leq 6.0$ olan çok sayıda, can ve mal kaybına neden olan deprem meydana gelmiștir. Bunlar arasında en kayda değerleri $1900(M \approx 5.0)$ ve $1945(M=5.8)$ Van depremleri ile 1941 (Ms=6.0) Erciș depremleridir (Șekil 1 ve 2) (Lahn, 1946; Tașman 1946; Ambraseys 1988). Bunlara yakın geçmiște meydana gelen $1988 \quad\left(m_{b}=5.3\right)$ ve $2000\left(M_{w}=5.7\right)$ Van depremleri eklenebilir 


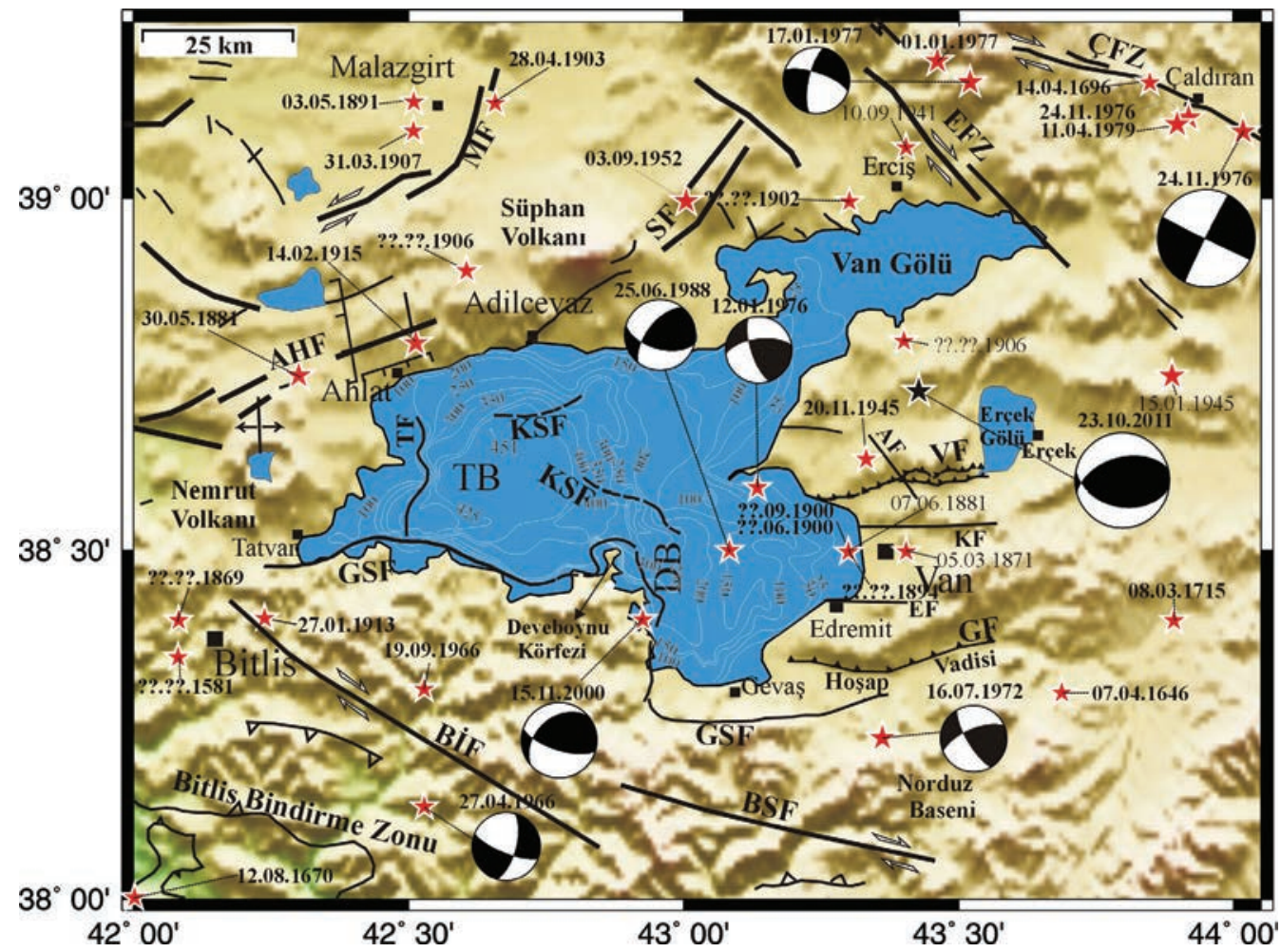

Șekil 2. Van Gölü bölgesinde yerel tektonik unsurlar (Koçyiğit, 2002; MTA, 2012) büyük depremlerin dıș merkez dağılımları, Van Gölü batimetrisi ve mevcut odak mekanizmaları. Depremlerin odak ve kaynak parametreleri için sırasıyla Tablo 1 ve 2'ye bakınız. KSF Northern Boundary Fault, GSF Southern Boundary fault, EFZ Erciș Fault Zone, ÇFZ Çaldıran Fault Zone, MT Muș Thrust, MF Malazgirt Fault, EF Edremit Fault, KF Kalecik Fault AF Alabayır Fault, DB Deveboynu Basin, TB Tatvan Basin, VF Van Fault, GF Gürpınar Fault.

Fig. 2. Local tectonic features (Koçyiğit, 2002; MTA, 2012), epicentral distribution of the large earthquakes (red and green stars), the bathymetry of Lake Van (Wong and Degens 1978) and available focal mechanisms for Lake Van area. See Table 1 and 2 for the hypocentral and the source parameters of the earthquakes, respectively. KSF Northern Boundary Fault, GSF Southern Boundary fault, EFZ Erciș Fault Zone, ÇFZ Çaldıran Fault Zone, MT Muș Thrust, MF Malazgirt Fault, EF Edremit Fault, KF Kalecik Fault AF Alabayır Fault, DB Deveboynu Basin, TB Tatvan Basin, VF Van Fault, GF Gürpınar Fault.

(Kalafat 1995; Pınar vd., 2007). 1988 ve 2000 Van depremleri göl havzasını sınırlayan sırasıyla KSF ve GSF üzerinde olușmuștur (Șekil 2). Bu depremler göl havzası içinde deprem etkinliğinin devam ettiğinin de önemli göstergeleridir.

\section{EKIM 2011 VAN DEPREMI $\left(M_{w} 7.1\right)$}

Bu deprem, 23 Ekim 2011 tarihinde Van Fayı üzerinde uluslararası zamana göre 10:41:21'de (yerel zamanla $13: 41: 21^{\prime} \mathrm{de}$ ) ve $38: 73^{\circ} \mathrm{K}-$ 43:43ํㅁ dıș merkezli olarak meydana gelmiștir (AFAD 2011; KRDAE 2011; USGS-NEIC; Erdik vd., 2011) (Tablo 2; Șekil 1 ve 2). Dıș merkez Van șehir merkezinin yaklașık 25 km KD'suna düșmektedir. Can kayıpları ve yıkım Van șehir merkezi ile Erciș ilçe merkezleri ile bu merkezler arasındaki kırsal yerleșimlerde meydana gelmiș olup en büyük can kaybı ve yıkım Erciș ilçe merkezinde gerçekleșmiștir (AFAD 2011; Çelebi vd., 2011; CEDIM 2011; METUIEERC, 2011; Erdik vd., 2012). Deprem, 604 kișinin ölümüne, 2608 kișinin yaralanmasına ve binlerce kișinin de evsiz kalmasına neden olmuștur. Bu kayıplar, 9 Kasım 2011 tarihinde meydana gelen $M_{\mathrm{w}}$ 5.7 büyüklüğündeki bir artçı depremle daha da artmıștır. Edremit ilçe merkezi yakınında bir dıș merkeze sahip olan bu artçı 40 ölüme daha yol açmıștır. Toplamda, 2011 Van depremi ve büyük arçıları 17000 civarında binanın ya 
Tablo 1. Van Gölü havzasında 1500 yılı sonrasında meydana gelen depremler. 1860 yılı öncesinde sadece zarar verici depremler dikkate alınırken 1860 yıı sonrasında büyüklüğü $M \geq 5.0$ olan tüm depremler dikkate alınmıștır. Episantral dağılım için Șekil 2'ye bakınız (Ambraseys, 1988, 1989, 2009), Ambraseys ve Finkel (1995), Kalafat vd., (2007) ve Albini vd., (2012)'den derlenmiștir).

Table 1. The earthquakes of the Lake Van area after 1500 AD. Only damaging earthquakes are listed till 1860 and all earthquakes with $M \geq 5.0$ are listed after that date. See Fig. 2 for the epicentral distribution. (compiled from Ambraseys (1988, 1989a, 1989b, 2009), Ambraseys and Finkel (1995), Kalafat vd., (2007) and Albini vd., (2012)).

\begin{tabular}{|c|c|c|c|c|c|c|c|c|}
\hline No. & Tarih & $\begin{array}{c}\text { Makrosismik } \\
\text { En.-Boy. } \\
\left({ }^{\circ}\right)\end{array}$ & $\begin{array}{c}\text { Aletsel } \\
\text { En.-Boy. } \\
\left({ }^{\circ}\right)\end{array}$ & $\begin{array}{l}\text { Der. } \\
\text { (km) }\end{array}$ & Şiddet & $M_{s}$ & $M_{w} \quad m_{b}$ & Açıklama \\
\hline 1 & 1581 & $38.35-42.10$ & & & VIII & & & Van-Bitlis \\
\hline 2 & 1626 & & & & & & & Hizan \\
\hline 3 & 07.04 .1646 & $38.30-43.70$ & & & $x$ & 6.7 & & Van \\
\hline 4 & 1669 & & & & & & & Van \\
\hline 5 & 12.08 .1670 & $38.00-42.00$ & & & & 6.7 & & Muș Bitlis \\
\hline 6 & 13.04.1692 & & & & & & & Adilcevaz \\
\hline 7 & 27.10 .1692 & & & & & & & Van \\
\hline 8 & 14.04 .1696 & & & & & 6.8 & & Çaldıran \\
\hline 9 & 10.06.1696 & & & & & & & Bitlis \\
\hline 10 & 26.03.1701 & & & & VII & & & Van-Pertek \\
\hline 11 & 27.01 .1705 & $38.70-41.70$ & & & IX & 6.7 & & Bitlis \\
\hline 12 & 08.03 .1715 & $38.40-43.90$ & & & IX & 6.6 & & Van \\
\hline $13^{*}$ & ??.??.1869 & $38.40-42.10$ & & & VI & $\approx 5.0$ & & Bitlis \\
\hline \multirow[t]{2}{*}{$14^{*}$} & 05.03.1871 & $38.50-43.40$ & & & & 5.5 & & \\
\hline & 30.05 .1881 & $38.75-42.30$ & & & & 6.3 & & Ahlat area \\
\hline $15^{\star}$ & 07.06 .1881 & $38.50-43.30$ & & & & $\approx 5.0$ & & \\
\hline 16 & 10.02 .1884 & $38.40-42.10$ & & & & 6.1 & & \\
\hline 17 & 03.05 .1891 & $39.15-42.50$ & & & & 6.0 & & \\
\hline $18^{*}$ & ??.??.1894 & $38.50-43.30$ & & & & $\approx 5.0$ & & \\
\hline $19^{*}$ & ??.06.1900 & $38.50-43.30$ & & & & $\approx 5.0$ & & Van \\
\hline $20^{*}$ & ??.09.1900 & $38.50-43.30$ & & & & $\approx 5.0$ & & Van \\
\hline 21 & ??.??.1902 & $39.00-43.30$ & & & & $\approx 5.0$ & & Erciș \\
\hline 22 & 28.04 .1903 & $39.14-42.65$ & & & & 7.0 & & Malazgirt \\
\hline 23 & ??.??.1906 & $38.90-42.60$ & & & & $\approx 5.0$ & & Nemrut \\
\hline 24 & ??.??.1906 & $38.80-43.40$ & & & & $\approx 5.0$ & & \\
\hline 25 & 31.03 .1907 & $39.10-42.50$ & & & & 5.2 & & Malazgirt \\
\hline
\end{tabular}




\begin{tabular}{|c|c|c|c|c|c|c|c|c|c|}
\hline No. & Tarih & $\begin{array}{c}\text { Makrosismik } \\
\text { En.-Boy. } \\
\left({ }^{\circ}\right)\end{array}$ & $\begin{array}{l}\text { Aletsel } \\
\text { En.-Boy. } \\
\left({ }^{\circ}\right)\end{array}$ & $\begin{array}{l}\text { Der. } \\
\text { (km) }\end{array}$ & Șiddet & $\mathbf{M}_{\mathrm{s}}$ & $\mathbf{M}_{\mathrm{w}}$ & $\mathrm{m}_{\mathrm{b}}$ & Açıklama \\
\hline $26^{*}$ & 27.01 .1913 & & $38.38-42.23$ & 10 & & 5.4 & & & \\
\hline $27^{*}$ & 14.02 .1915 & & $38.80-42.50$ & $?$ & & 5.6 & & & \\
\hline $28^{*}$ & 15.01 .1945 & $38.47-43.30$ & $38.75-43.89$ & 10 & & $4.9-5.0$ & & & Van \\
\hline $29^{*}$ & 20.11 .1945 & $38.44-43.49$ & $38.63-43.33$ & 10 & & $5.5-5.8$ & & & Van \\
\hline 30 & 03.09.1952 & & $39.00-43.00$ & 12 & & 5.5 & & & \\
\hline 31 & 27.04 .1966 & & $38.13-42.52$ & 40 & & 5.6 & & 5.1 & \\
\hline 32 & 19.09 .1966 & $39.16-41.53$ & $38.30-42.52$ & 35 & & & & 5.2 & \\
\hline $33^{*}$ & 16.07 .1972 & & $38.23-43.36$ & 46 & & & & 5.0 & Van \\
\hline $34^{*}$ & 12.01 .1976 & & $38.59-43.13$ & 36 & & & & 5.0 & Van \\
\hline 35 & 24.11 .1976 & & $39.10-44.02$ & 10 & & 7.3 & & & Çaldıran \\
\hline 36 & 24.11 .1976 & & $39.12-43.92$ & 33 & & & & 5.0 & \\
\hline 37 & 24.11 .1976 & & $39.02-44.18$ & 40 & & & & 5.0 & Muradiye \\
\hline 38 & 01.01 .1977 & & $39.20-43.46$ & 24 & & & & 5.0 & \\
\hline 39 & 17.01 .1977 & & $39.17-43.52$ & 33 & & & & 5.0 & Çaldıran \\
\hline 40 & 11.04 .1979 & & $39.11-43.90$ & 34 & & & & 5.0 & \\
\hline $41^{*}$ & 25.06 .1988 & & $38.50-43.08$ & 50 & & & & 5.3 & Van \\
\hline \multirow[t]{2}{*}{$42^{*}$} & 15.11 .2000 & & $38.40-42.92$ & 23 & & & 5.7 & & Van \\
\hline & 23.10.2011 & & $38.73-43.43$ & 5 & & & 7.1 & & Van \\
\hline
\end{tabular}

tamamen yıkılmasına ya da tamir edilemeyecek șekilde hasar görmesine yol açmıștır.

2011 Van depremi için çeșitli sismoloji enstitü ve kurulușlarınca bulunan odak ve kaynak parametreleri Tablo 2'de verilmiș olup yapılan kaynak mekanizma çözümleri deprem için ters faylanma mekanizması önermektedir. Kaynak mekanizma çözümleri Van depreminin meydana geldiği Van fayının arazide gözlenen karakteri ile tam bir uyum sergilemektedir (Emre vd., 2011; Akyüz vd., 2011; AFAD, 2011; JMO, 2011) (Șekil 2). Erçek ve Van gölleri arasında yaklașık 22 km bir uzaklık boyunca kabaca doğu-batı doğrultusunda uzanan Van Fayı doğuda kalan 12 km'lik bölümünde bir birinden birkaç $\mathrm{km}$ uzaklıkla ayrılan iki iz halinde haritalanmıștır.
Deprem Van Fayının doğudaki yarısı boyunca devamsız gözlenen ve yüzey kırığı olarak nitelendirilebilecek belirgin olmayan bazı yüzey deformasyonlarına neden olmuștur. Bu yüzey deformasyonları boyunca $10-30 \mathrm{~cm}$ arasında düșey yer değiștirmeler ölçülmüș olup bir iki noktada sol yanal yer değiștirmeler de rapor edilmiștir. (Emre vd., 2011)

Van fayı, K-KD eğimli olup kuzeydeki fay bloğu üste bindiren tavan bloğunu teșkil etmektedir. Sismolojik ve jeodezik verilerin modellenmeleri sonucu 4-7 m derinliğine kadar düșey kayma belirlenmesi ve belirgin yüzey kırıklarının gözlenmemesi faylanmanın dolayısıyla da Van Fayının kör bir fay olduğunu önermektedir (Hayes vd., 2011; Atzori vd., 2011; Utkucu 2013; Irmak 
Tablo 2. Van Gölü bölgesinde kaynak parametreleri bilinen depremler. Odak parametreleri KRDAE ve USGS kataloglarından derlenmiștir.

Table 2 The earthquakes with known source parameters occurred in the Lake Van Area. Hypocentral parameters have been compiled from the KRDAE and USGS catalogues.

\begin{tabular}{cccccccc}
\hline $\begin{array}{c}\text { Latitude } \\
\left({ }^{\circ}\right)\end{array}$ & $\begin{array}{c}\text { Longitude } \\
\left({ }^{\circ}\right)\end{array}$ & $\begin{array}{c}\text { Depth } \\
(\mathrm{km})\end{array}$ & Strike $\left(^{\circ}\right)$ & Dip ( $\left.{ }^{\circ}\right)$ & Rake ( $\left.{ }^{\circ}\right)$ & $\begin{array}{c}\text { Mo } \\
\left(\times 10^{16} \mathrm{Nm}\right)\end{array}$ & Magnitude
\end{tabular}

\subsubsection{6}

MK

42.50

40

112

74

$-155$

$m_{b} 5.0$

16.07.1972 Gevaș

UT 38.23

43.36

46

247

66

18

$m_{b} 5.0$

12.01.1976 Van

UT $\quad 38.59$

43.13

36

262

63

21

$m_{b} 5.0$

\subsubsection{6 Çaldıran}

P

17.01.1977

$\mathrm{KL}$

39.17

43.52

33

289

71

$-160$

$m_{b} 5.0$

25.06.1988 Van

USGS

GCMT

38.44

43.08

15

106

57

144

$M_{w} 5.5$

15.11.2000 Van

P_RMT

20

102

68

120

16.2

$M_{w} 5.4$

02.12.2001

ZUR_RMT

38.43

43.25

18

262

40

98

1.63

$M_{w} 4.8$

\subsubsection{4}

ZUR_RMT

38.61

43.31

15

263

49

87

0.72

$M_{w} 4.5$

05.05.2007 Ahlat
K_RMT

38.73

42.21

16

281

70

$-179$

0.02

$M_{w} 4.2$

26.07.2008 Lake Van

K RMT

43.10

5

24

88

37

0.13

$\mathrm{M}_{\mathrm{w}} 4.4$

23.10.2011 Van

$\begin{array}{lll}\text { KRDAE } & 38.73 & 43.43 \\ \text { USGS }^{1} & 38.69 & 43.49 \\ \text { USGS }^{2} & 38.69 & 43.49 \\ \text { GCMT } & 38.67 & 43.42\end{array}$

$6.4^{*}$

$M_{w} 7.2$

16

241

51

58

$5.6^{\star}$

$M_{w} 7.1$

12

246

38

60

$6.4^{*}$

$M_{w} 7.2$ 


\begin{tabular}{|c|c|c|c|c|c|c|c|c|}
\hline & $\begin{array}{c}\text { Latitude } \\
\left({ }^{\circ}\right)\end{array}$ & $\begin{array}{l}\text { Longitude } \\
\quad\left({ }^{\circ}\right)\end{array}$ & $\begin{array}{c}\text { Depth } \\
(\mathbf{k m})\end{array}$ & Strike $\left(^{\circ}\right)$ & Dip ( $\left.{ }^{\circ}\right)$ & Rake $\left(^{\circ}\right)$ & $\begin{array}{c}\text { Mo } \\
\left(\times 10^{16} \mathrm{Nm}\right)\end{array}$ & Magnitude \\
\hline GFZ & 38.72 & 43.55 & 10 & 268 & 36 & 85 & $4.7^{\star}$ & $M_{w} 7.1$ \\
\hline EMSC & 38.86 & 43.48 & 10 & 248 & 53 & 64 & $6.8^{\star}$ & $M_{w} 7.3$ \\
\hline
\end{tabular}

MK= McKenzie (1972); UT= Utkucu (2013); P= Pınar (1995)'in uzak-alan verilerinden toplam çözüm kaynak parametreleri; KL= Kalafat (1998); P_RMT= Pınar vd., (2007) RMT (Regional moment tensor) çözümü; K_RMT =Kılıç ve Utkucu (2012) RMT çözümü; KRDAE=Kandilli Rasathanesi ve Deprem Araștırma Enstitüsü; ZUR_RMT=Zurich Regional Moment Tensor; GFZ= German Research Centre for Geoscience; GCMT= Global Centroid Moment Tensor Catalog; USGS1= United States Geological Survey body-wave moment tensör çözümü; USGS2= United States Geological Survey WPhase centroid moment tensör çözümü. * $\left(x 10^{19} \mathrm{Nm}\right)$

vd., 2012). Deprem Van Gölü'nün Van Fayı tavan bloğu üzerinde kalan sahil șeridinde 10$30 \mathrm{~cm}$ yükselmeye neden olmuștur (Emre vd., 2011).

2011 Van depremi toplamda $51 M w \geq 4.6$ depremi içeren önemli bir artçı deprem etkinliğine de neden olmuștur. Kandilli Rasathanesi Deprem Araștırma Enstitüsü (KRDAE) tarafından konumları belirlenen ve Nisan 2012'ye kadar olușmuș artçı depremler Șekil 3'de gösterilmiștir. GCMT tarafından kaynak mekanizma çözümü yapılan $16 \mathrm{Mw} \geq 4.6$ artçı depremin kaynak parametreleri Tablo 3'de verilmiș olup bu kaynak mekanizmaları Șekil 3'de gösterilmiștir. Gerek artçı deprem konumları gerekse kaynak mekanizma çözümleri birçok artçı depremin anașoku üreten Van fayı üzerinde olușmadığını, ana șok kırılması yakın civarında uzanan özellikle doğrultu atımlı faylanma mekanizmalı faylar üzerinde oluștuğunu (off-fault aftershocks) önermektedir.

\section{VAN DEPREMI KIRILMA EVRIMI}

Utkucu (2013), Hartzell ve Heaton (1983) tarafından geliștirilmiș bir sonlu-fay ters çözüm yöntemini 2011 Van depremi uzak-alan cisim dalgalarına uygulamıș ve bu deprem için bir kayma dağılımı elde edilmiștir. Bu çalıșmada, deprem için yapılan bu sonlu-fay analizi, zaman penceresi yaklașımı (Hartzell ve Heaton 1983; Wald ve Heaton 1994) bağlamında irdelenip daha da ileri götürülerek kırılmanın sonlu-fay uzay-zaman evrimi yorumlanmaya çalıșılacaktır. Kullanılan sonlu-fay ters çözüm analizinin ayrıntıları Hartzell ve Heaton (1983) ve Wald ve Heaton (1994)'de verilmiș olup burada kısaca model- leme için kullanılan parametrizasyon hakkında bilgi verilecektir.

Belirgin bir yüzey kırığı gözlenmediği için deprem kırılma boyutları belirsiz olduğundan kırıma düzlemini temsil için $70 \mathrm{~km} \times 35 \mathrm{~km}$ boyutlarında oldukça geniș bir düzlem seçilmiș ve KRDAE dıș merkezi doğrultu boyunca ortaya gelecek șekilde kırılma düzlemi kaynak bölgesine yerleștirilmiștir. Depremin dıș merkez izdüșümü kırılma düzlemini $16 \mathrm{~km}$ derinlikte kesmektedir. Kırılma düzlemi 98 kare șeklinde fay parçasına (doğrultu boyunca 14, eğim boyunca 7 fay parçası) bölünerek kaymanın uzaysal dağııımının elde edilmesi amaçlanmıștır. Yapılan birkaç denemeden sonra kullanılan veriye (ilk $P$ dalga varıșından itibaren 50 sn uzunluğunda bir zaman penceresi ile seçilmiș $31 P$ ve $9 \mathrm{SH}$ dalga șekli) en iyi uyumu veren kaynak parametrelerinin USGS-Cisim dalgası moment tensör çözümünden belirlenen parametreler (doğrultu 255, eğim 50 , rake 73 ) olduğu belirlenmiștir (Tablo 2 , Șekil 2 ve 3).

Kırılmanın karmașıklığı ve değișen kırıma hızları durumları için 8 zaman penceresi kullanılarak modellemede esneklik sağlanmıștır. Her bir zaman penceresi içindeki kayma evrimi $0.5 \mathrm{sn}$ yükselim ve düșümlü, ikiz kenar üçgen șeklinde, zamanca örtüșmeyen yükselim-zaman fonksiyonu ile temsil edilmiștir. Böylelikle kırılma düzlemi üzerinde her bir noktada gerek duyulduğu takdirde toplamda 8 sn'lik uzun bir kayma süresine ve tanımlanan en büyük kırılma hızına (3.3 km/sn) göre daha küçük kırıma hızlarına modellemede izin verilmiștir. Yapılan bu sonlu-fay parametrizasyonu ile her bir fay parçasına karșlık gelen sentetik sismogramlar genelleștirilmiș ıșın 


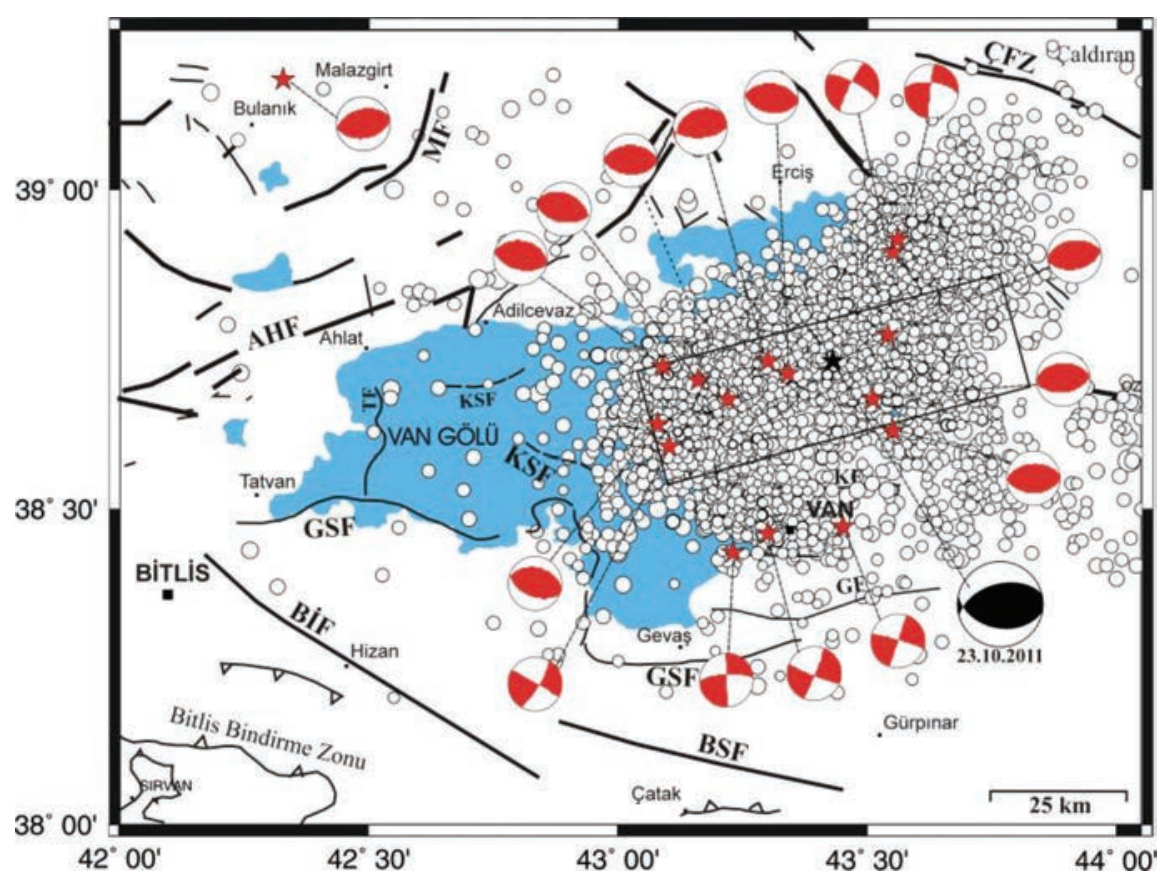

Șekil 3. Van Gölü Bölgesi'nin yerel tektonik unsurları ve Nisan 2012 tarihine kadar olușmuș KRDAE tarafından sağlanan 2011 Van depremi artçı depremlerinin (beyaz daireler) dıș merkez dağılımları. GCMT kaynak mekanizmaları (kırmızı-beyaz plaj topları) mevcut olan $\mathrm{M} \geq 4.6$ artçı depremler kırmızı yıldızlarla gösterilmiștir. Siyah yıldız ve dikdörtgen sırasıyla 2011 Van Depremi dıș merkezini ve uzak-alan sonlu fay analizinde kullanılan kırılma düzleminin yüzey izdüșümünü temsil etmektedir. Aktif fay referansları ve kısaltmaları için Șekil 2'nin alt yazısına bakınız.

Figure 3. Local tectonic features of the Lake Van area and the epicentre distribution of the 2011 Van earthquake aftershocks (white filled circles) occurred until April 2012 and provided by Kandilli Observatory and Earthquake Research Institute. The $M \geq 4.6$ aftershocks with available GCMT source mechanisms (red-white beach balls) are shown with red stars. The black star and the rectangle denote the epicentre of the 2011 Van earthquake and surface projection of the rupture plane used in the teleseismic finite- fault analysis, respectively. See caption of Figure 2 for the active fault references and abbreviations.

yöntemiyle (Langston ve Helmberger 1975) ve Pınar vd., (2007)'de verilen kabuksal hız yapısı (Tablo 4) kullanılarak ters çözümde kullanlan her bir istasyonda hesaplanmıștır. Hesaplanan yapay dalga șekilleri gözlenmiș dalga șekilleri ile en küçük kareler ters çözümü (Lawson ve Hanson 1974) bağlamında benzetilerek her bir fay parçasına karșilık gelen kayma değerleri hesaplanmıștır. 2011 Van depremi için yapılan bu sonlu-fay modellemesinin diğer ayrıntıları Utkucu (2013)'de verilmiștir.

Utkucu (2013)'nin bulduğu sonlu-fay kayma dağılım modeli Șekil 4'de verilmiștir. Sonlu-fay modeli kırılmanın odaktan itibaren $30 \mathrm{~km}$ boyunca tek taraflı olarak GB'ya ve eğim yukarı yayıldığını, 5 km'den sığ derinliklere ilerlemediğini ve en büyük kayma değerinin yaklașık 5.5 $\mathrm{m}$ olduğunu önermektedir. Zaman penceresi yaklașımında kullanılan her bir zaman penceresi içinde hesaplanan kayma dağııımları Șekil 5'de verilmiștir. Șekil 5'den görüldüğü üzere kayma en büyük değerine ilk zaman penceresinde sahiptir ve kaymanın önemli bir kısmı llk 3 zaman penceresi içinde gerçekleșmiștir. Diğer (ilk 3 zaman penceresi sonrasındaki) zaman pencereleri içindeki kayma inmal edilebilir değerlerdedir ve büyük olasılıkla modellemede yükselim zamanında sağlanan fazla esneklikten dolayı ters çözümleme sonucu bulunan yapay kaymalardır. Buna göre, yapılan sonlu-fay analizi sonucu kullanılan veriden 2011 Van depremi için yükselim zamanı 3 sn olarak bulunmuștur. Yani kırılma düzlemi üzerinde herhangi bir noktada kayma süresi 3 sn'yi așmamaktadır. Kayma odak bölgesinde 1 sn, en büyük kaymanın gözlendiği 
Tablo 3. 23 Ekim 2011 Van depreminin GCMT katalogunda kaynak mekanizma çözümü verilen artçı depremleri ve odak parametreleri (Kandilli Rasathanesi Deprem Araștırma Enstitüsü, GCMT ve USGS-NEIC kataloglarından derlenmiștir).

Table 3. The aftershocks with source mechanism solutions given in GCMT catalogue of the 23 October 2011 Van earthquake along with their hypocentral parameters (compiled from Kandilli Observatory and Earthquake Research Institute, GCMT and USGS-NEIC catalogues).

\begin{tabular}{|c|c|c|c|c|c|c|c|c|c|c|c|c|}
\hline No & $\begin{array}{l}\text { Date } \\
\text { (GMT) }\end{array}$ & $\begin{array}{l}\text { Origin } \\
\text { time } \\
\text { (GMT) }\end{array}$ & $\begin{array}{l}\text { Latitude } \\
\quad\left({ }^{\circ}\right)\end{array}$ & $\begin{array}{l}\text { Longitude } \\
\quad\left(^{\circ}\right)\end{array}$ & Depth & Mw & ML & $\mathrm{mb}$ & $\begin{array}{c}\text { Strike } \\
\left({ }^{\circ}\right)\end{array}$ & $\begin{array}{l}\text { Dip } \\
\left({ }^{\circ}\right)\end{array}$ & $\begin{array}{c}\text { Rake } \\
\left({ }^{\circ}\right)\end{array}$ & $\begin{array}{c}\text { CMT } \\
\text { depth } \\
(\mathrm{km}) \\
\end{array}$ \\
\hline 1 & 23.10.2011 & 18.10 .45 & 38.7102 & 43.3382 & 5 & & 5.0 & 5.1 & $100 / 275$ & $45 / 45$ & $93 / 87$ & 20.9 \\
\hline 2 & 23.10 .2011 & 20.45 .34 & 38.6345 & 43.0775 & 5 & 6.0 & 5.7 & 6.0 & $281 / 111$ & $40 / 50$ & $82 / 96$ & 12.0 \\
\hline 3 & 24.10 .2011 & 08.28 .26 & 38.6200 & 43.5500 & 3 & & & 4.8 & $92 / 265$ & $45 / 45$ & $94 / 86$ & 22.0 \\
\hline 4 & 24.10 .2012 & 08.49 .21 & 38.6700 & 43.5100 & 7 & & & 4.9 & 268/82 & $41 / 49$ & $94 / 86$ & 20.2 \\
\hline 5 & 24.10 .2011 & 15.28 .06 & 38.6737 & 43.2243 & 5 & & 4.8 & 4.9 & $269 / 93$ & $44 / 46$ & $87 / 93$ & 18.5 \\
\hline 6 & 25.10 .2011 & 14.55 .08 & 38.7733 & 43.5468 & 5 & 5.6 & 5.4 & 5.7 & $264 / 79$ & $43 / 47$ & $94 / 86$ & 14.4 \\
\hline 7 & 26.10 .2011 & 03.16 .18 & 38.7300 & 43.300 & 5 & & & 4.7 & $102 / 239$ & $36 / 32$ & $127 / 66$ & 30.6 \\
\hline 8 & 29.10 .2011 & 22.24.22 & 38.8985 & 43.5503 & 5 & & 5.3 & 5.0 & $298 / 206$ & $77 / 82$ & $-172 /-14$ & 19.4 \\
\hline 9 & 06.11 .2011 & 02.43 .12 & 38.9243 & 43.5650 & 5 & & 4.9 & 4.7 & $277 / 186$ & $64 / 87$ & $-176 /-26$ & 15.8 \\
\hline 10 & 08.11 .2011 & 22.05 .51 & 38.7242 & 43.0870 & 4.3 & 5.2 & 5.5 & 5.6 & $280 / 104$ & $37 / 53$ & $87 / 92$ & 21.2 \\
\hline 11 & 09.11 .2011 & 19.23 .33 & 38.4295 & 43.2342 & 5 & 5.6 & 5.6 & 5.6 & $267 / 358$ & $72 / 89$ & $179 / 18$ & 13.5 \\
\hline 12 & 14.11.2011 & 22.08 .16 & 38.6973 & 43.1578 & 7.8 & & 5.2 & 5.3 & 296/98 & $40 / 51$ & $104 / 78$ & 17.3 \\
\hline 13 & 18.11.2011 & 17.39 .43 & 38.6000 & 43.1000 & 10 & & & 5.0 & $31 / 300$ & $77 / 88$ & $2 / 167$ & 16.7 \\
\hline 14 & 30.11 .2011 & 00.47 .21 & 38.4740 & 43.4530 & 4.3 & & 5.0 & 4.9 & $287 / 17$ & $86 / 89$ & $179 / 4$ & 28.4 \\
\hline 15 & 04.12 .2011 & 22.15 .02 & 38.4600 & 43.3000 & 4.7 & & & 4.7 & $112 / 22$ & $84 / 87$ & $-177 /-6$ & 24.3 \\
\hline 16 & 26.03.2012 & 10.35 .32 & 39.1700 & 42.3300 & 5 & 5.0 & & -- & $82 / 256$ & $44 / 46$ & $94 / 86$ & 19.5 \\
\hline
\end{tabular}

yerde 3 sn sürmüștür. Özellikle, fayın GB üst köșesindeki sığ kaymanın 8nci zaman penceresi içinde gerçekleșmesi, sığda gözlenen bu kaymanın kayma yükselim zamanında modellemede sağlanan așırı esneklikten kaynaklandığını önermektedir. Nitekim Utkucu (2013), bulduğu Șekil 4'deki kayma modelinden yüzey dislokasyonlarını hesaplamıș ve GB sığ kaymanın olmaması durumunda hesaplanan dislokasyonların Van Gölü sahil șeridindeki yükselme gözlemlerini daha iyi karșıladığını öne sürmüștür. Zaman penceresi yaklașımı sonuçları faylanmanın kör faylanma olduğunu destekler niteliktedir.

Șekil 5'de verilen her bir zaman-penceresi içindeki kayma dağılımları, tanımlanan en büyük kırılma hızına göre odaktan kırılmanın dairesel yayılması göz önüne alınarak belirli zaman aralıkları içindeki kayma dağılımlarının bulunmasında yani kayma hızının uzay-zaman evriminin elde edilmesinde kullanılabilir. Birer saniye zaman aralıklarıyla yapılan ve kırılmanın uzay-zaman evriminin eldesi anlamını tașıyan bu ișlemin sonucu olan kayma dağılımları Șekil 6'da gösterilmiștir. Kırılma ilk 3 saniyede 0.5 m'lik kayma değerini pek așmamıștır. 4ncü saniyede kayma $1 \mathrm{~m}$ genliğini așmıș ve $6 \mathrm{nc}$ s saniyede en büyük kayma $(2.6 \mathrm{~m})$ meydana gelmiștir. İlk 7 sn boyunca $3.3 \mathrm{~km} / \mathrm{sn}$ hızla yayılan kırımanın 8nci saniyeden itibaren yavașlamaya bașladığı, 9ncu saniyede önemli kaymalar için $2.3 \mathrm{~km} / \mathrm{sn}$ hızına kadar yavașladığı ve 2 sn sonrada durduğu anlașılmaktadır. Toplam kırılma süresi yaklașık 11 sn'dir ve göreceli olarak önemli sismik 
Tablo 4. 23 Ekim 2011 Van depremi sonlu-fay kırılma evrimi analizi ve 3 artçı depreminin nokta kaynak ters çözümlerinde kullanılan kabuksal hız modeli (Pınar vd., 2007).

Table 4. Crustal velocity structure used in this study for the finite-fault rupture analysis of the 23 October 2011 Van earthquake and for the point-source inversion of its 3 aftershocks (PInar et al., 2007).

\begin{tabular}{cccc}
\hline Kalınlık $(\mathrm{km})$ & $\mathrm{V}_{\mathrm{p}}(\mathrm{km} / \mathrm{sn})$ & $\mathrm{V}_{\mathrm{s}}(\mathrm{km} / \mathrm{sn})$ & $\mathrm{r}\left(\mathrm{kg} / \mathrm{m}^{3}\right)$ \\
\hline 2 & 4.50 & 2.60 & 2210 \\
6 & 5.54 & 3.20 & 2540 \\
10 & 6.23 & 3.60 & 2460 \\
12 & 6.92 & 4.00 & 2980 \\
- & 7.78 & 4.50 & 3260 \\
\hline
\end{tabular}

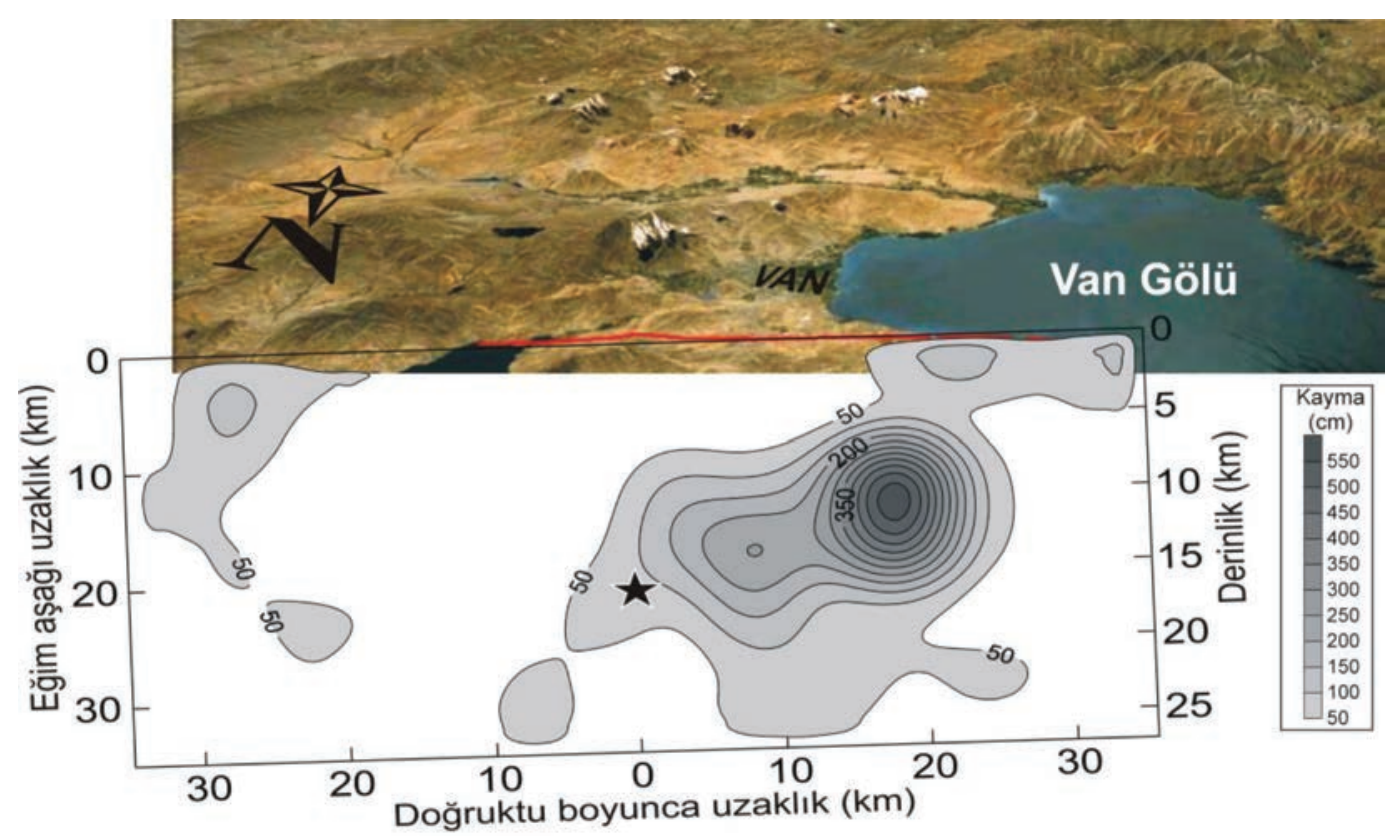

Șekil 4. 23 Ekim 2011 Van depreminin Utkucu (2013) tarafından bulunmuș kayma dağılım modeli. Kayma $0.5 \mathrm{~m}$ arayla 0.5 m'den büyük değerleri için konturlanmıștır. Siyah yıldız depremin odağını temsil etmektedir.

Fig. 4. Slip distribution model of the October 23, 2011 Van earthquake obtained by Utkucu (2013). The slip values are contoured at $0.5 \mathrm{~m}$ interval for the slip larger than $0.5 \mathrm{~m}$. The solid star represents the hypocentre.

moment serbestlenmesi 5-9 sn zaman aralığında gerçekleșmiștir. Serbestlenen toplam sismik moment $4.6 \times 10^{19} \mathrm{Nm}$ 'dir $\left(\mathrm{M}_{\mathrm{w}}=7.1\right)$.

\section{ARTÇI DEPREM NOKTA-KAYNAK TERS ÇÖZÜMLERi}

2011 Van depremi anașokun olușturduğu can ve mal kayıplarını arttıran önemli bir artçı deprem etkinliğine neden olmuștur. Özellikle 9 Kasım 2011 tarihinde Edremit ilçe merkezi yakınında bir dıș merkeze sahip artçı deprem diğerlerine göre gerek olușturduğu can kaybı ve yıkım gerekse anașoku olușturan faydan farklı bir fay üzerinde ve farklı faylanma mekanizması ile olușmasıyla ilgi çekmiștir. Bu nedenle artçı deprem kaynak mekanizmaları ve kaynak özellikleri önem kazanmaktadır. Burada büyüklüğü $M w \geq 5.6$ olan 3 artçı depremin (Tablo 3'de 2, 6 ve 11 nolu depremler) nokta kaynak ters çözümü Kikuchi ve Kanamori (1991) tarafından geliștirilen bir yöntemle uzak-alan cisim dalgaları kullanılarak yapılmıștır. Kullanılan verinin çözünürlülüğü gözetilerek alt magnitude eșiği $M \mathrm{w}=5.6$ alınmıștır. 

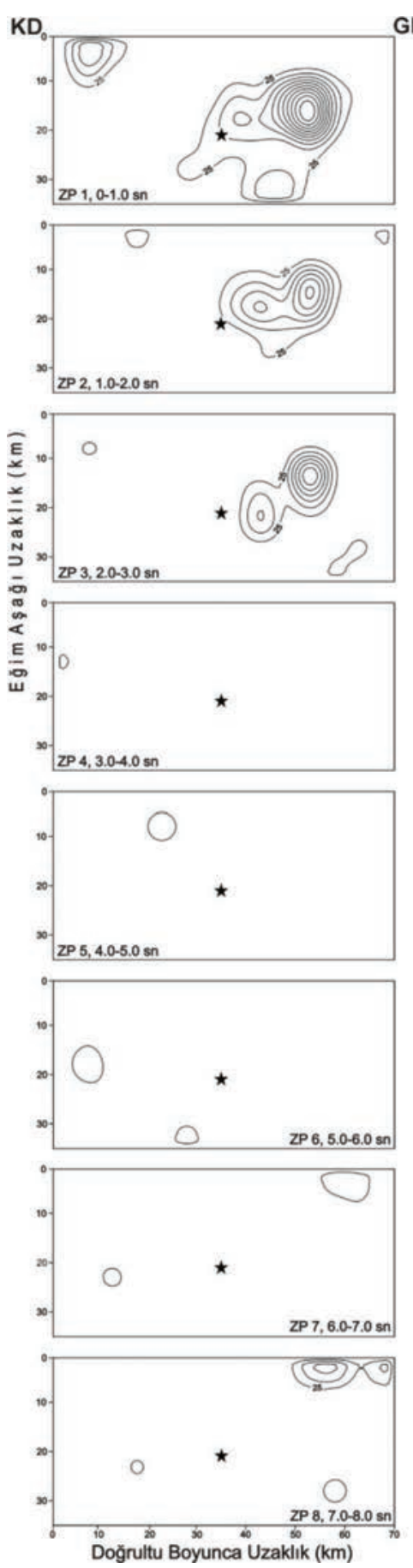

Șekil 5. Her bir zaman-penceresinin Șekil 4'de veriIen toplam kayma dağılımına katkılarının ayrı ayrı gösterildiği zaman-penceresi analizi sonuçları. Pencerelerin kapsadığı zaman aralıkları her bir pencerenin sol ve sağ altında verilmiștir.

Figure 5. Time-window analysis results by means of individual time-window contributions for the total slip model given in Fig. 4. The time interval represented by each window are given at the bottom left and right of the vindows.

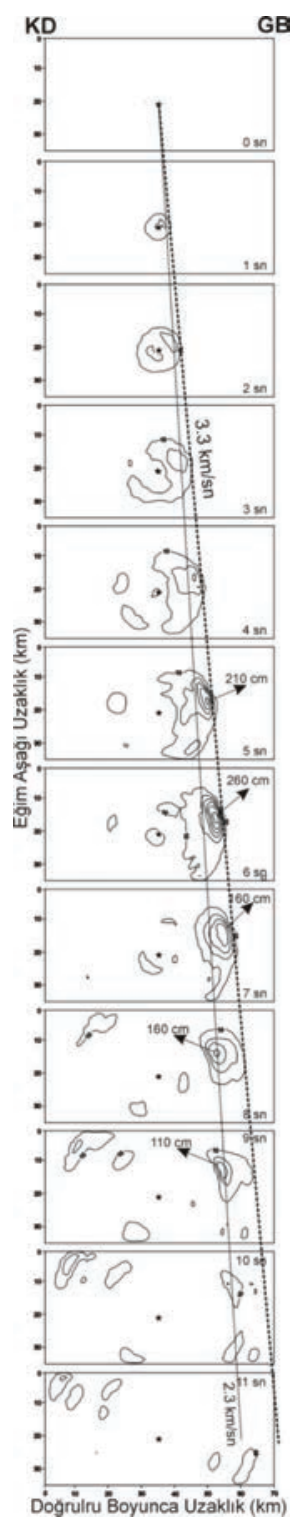

Șekil 6. 2011 Van depremi kırımasının 1 sn zaman aralıkları ile verilen uzay-zaman evrimi. 10 cm'den büyük kaymalar $50 \mathrm{~cm}$ kontur aralıklarıyla çizilmișlerdir. Her bir zaman aralığında kırımanın ilerleyiș hızı hakkında fikir edinilmesi için 3.3 ve $2.3 \mathrm{~km} / \mathrm{sn}$ hızında ilerleyen dairesel kırıma cephelerine teğet geçen doğrular kıııma hızı referansı için çizilmiștir. Siyah yıldız deprem odağını göstermektedir.

Figure 6. Space-time evolution of the 2011 Van earthquake rupture given at time intervals of 1 second. The slips larger than $10 \mathrm{~cm}$ are contoured at intervals of $50 \mathrm{~cm}$. To have an idea about the rupture velocity at each time interval, the lines that are tangent to the radially propogating rupture fronts at velocity of 3.3 and $2.3 \mathrm{~km} / \mathrm{sn}$ are drawn for reference. The black star denotes the hypocentre. 
Artçı depremlerin nokta kaynak ters çözümlemesinde kullanılan veriler Tablo 5'de verilmiștir. Kullanılan veri, 0.01-0.33 Hz frekans aralığında bant geçișli filtrelenmiș olup ters çözümlemede içerilen istasyonlar $30^{\circ}-90^{\circ}$ aralığında dıș merkez uzaklıklarına sahiptirler. Verilerin bașlangıç zamanları Jeffreys ve Bullen (1958) zaman çizelgeleri yardımıyla belirlenmiș ve gözle yapılan kontroller sonucunda gerek duyulduğu durumlarda Yer içinin heterojen yapısı dikkate alınarak bu bașlangıç zamanları zamanca bir kaç sn ileri geri kaydırılmıștır.

Yöntemin uygulanması için deprem kaynağının bir nokta kaynak gridi ile temsili gerekmektedir. 3 deprem için kullanılan nokta kaynak gridleri Șekil 7'de gösterilmiștir. Bu düzlemsel gridler üzerindeki her bir nokta kaynak 5 bağımsız moment tensörle temsil edilmiștir. Șekil 7'den görüldüğü gibi Green's fonsiyonları (yapay sismogramlar) 5 farklı derinlik için tayin edilen referans noktasına göre Tablo 4'de verilen hız yapısı kullanılarak hesaplanmıștır. Yineleyen ters çözümlerle yapay sismogramların gözlenmiș sismogramlara benzetimi yoluyla belirlenen bu bağımsız moment tensörlerin kombinasyonu incelenen depremin kaynak mekanizmasını vermektedir. Burada kısaca özetlenen yöntemin ayrıntıları Kikuchi ve Kanamori (1991) ve Pınar (1995)'de verilmiștir.

3 artçı deprem için de tek kaynakla gözlenmiș verilere tatmin edici bir uyum sağlanmıștır. Yineleyen ters çözümleme sonucu elde edilen kaynak mekanizmaları Șekil 8, 9 ve 10'da yapaygözlenmiș dalga șekli karșılaștırmasıyla birlikte gösterilmiș ve elde edilen kaynak mekanizmalarına ait kaynak parametreleri ise Tablo 5'de verilmiștir. Bulunan kaynak çözümler Tablo 3'de verilen GCMT çözümleriyle karșılaștırıldığında, farklı frekans bandındaki verilerden elde edilen çözümler olmasına rağmen gerek faylanma türü, gerekse faylanma parametreleri açısından genel benzerlik dikkat çekicidir. En önemlisi de yapılan nokta kaynak ters çözümünün $9 \mathrm{Kasım}$ 2011 tarihli artçı deprem için GCMT gibi doğrultu atımlı faylanma mekanizması vermesi ve bu artçının bașka bir fay üzerinde meydana geldiğini önermesidir. Ancak, bu artçı için bulunan çözümde $D-B$ doğrultulu düğüm düzleminin eğiminin GCMT çözümündekinden daha düșük açılı olduğu da vurgulanmalıdır.

\section{GERILME TENSÖRÜ ANALIZi}

Pınar vd., (2007) Van Gölü bölgesi içinde gerilme rejiminin transpresif bir gerilme rejimi olduğunu ve bu yönüyle yerel olarak doğrultu-atımlı rejimin baskın olduğu Doğu Anadolu bölgesi genelinden farklıık gösterdiğini belirlemiștir. Bu çalıșmada da benzer yöntemle bir gerilme tensör analizi veri olarak Tablo 2'de listelenmiș kaynak parametreleri bilinen depremler ve bu depremlere ilave olarak Tablo 3'de verilen 2011 Van depremi artçı depremleri mekanizma çözümleri içerilerek ayrı ayrı yapılmıștır.

Yöntemde kullanılan veriler deprem odak mekanizmalarından belirlenmiș $P$ ve $T$ gerilme eksenlerinin yönelimleridir yani azimut ve daIımlarıdır. Yöntem en büyük asal gerilme ( $\sigma 1)$,

Tablo 5. Tablo 3'de verilen 2, 6 ve 11 nolu artçı depremler için yapılan uzak-alan nokta-kaynak ters çözümünde kullanılan verinin özellikleri ve ters çözüm sonucunda elde edilen kaynak parametreleri.

Table 5. The features of the teleseismic data used in the point-source inversion of the aftershocks numbered 2, 6 and 11 in Table 3 along with the source parameters resulted from the inversion.

\begin{tabular}{cccccccccccc}
\hline \multicolumn{1}{c}{ Artçı } & \multicolumn{4}{c}{ Kullanılan uzak-alan verisi } & \multicolumn{4}{c}{ Ters Çözüm Sonuçları } \\
\hline $\begin{array}{c}\text { Oluș } \\
\text { zamanı }\end{array}$ & $\mathbf{P}$ & $\mathbf{S H}$ & $\begin{array}{c}\text { Veri } \\
\text { boyu } \\
\text { (sn) }\end{array}$ & $\begin{array}{c}\text { Örnekleme } \\
\text { Aralığı(sn) }\end{array}$ & $\begin{array}{c}\text { Doğrultu } \\
\text { (o) }\end{array}$ & $\begin{array}{c}\text { Eğim } \\
\text { (o) }\end{array}$ & $\begin{array}{c}\text { Rake } \\
\text { (o) }\end{array}$ & $\begin{array}{c}\text { CMT } \\
\text { derinliği }\end{array}$ & $\begin{array}{c}\text { Sismik } \\
\text { Moment } \\
\mathbf{X} 10^{17} \\
\text { Nm }\end{array}$ & $\begin{array}{c}\text { Mw } \\
\text { Nm }\end{array}$ \\
\hline $23 / 10 / 2011$ & 36 & 14 & 20 & 0.5 & 268 & 50 & 74 & 13 & 0.8 & 5.9 \\
$25 / 10 / 2011$ & 31 & 5 & 20 & 0.5 & 279 & 41 & 78 & 9 & 0.38 & 5.7 \\
$09 / 11 / 2011$ & 23 & 11 & 20 & 0.5 & 275 & 36 & -166 & 5 & 0.31 & 5.6 \\
\hline
\end{tabular}




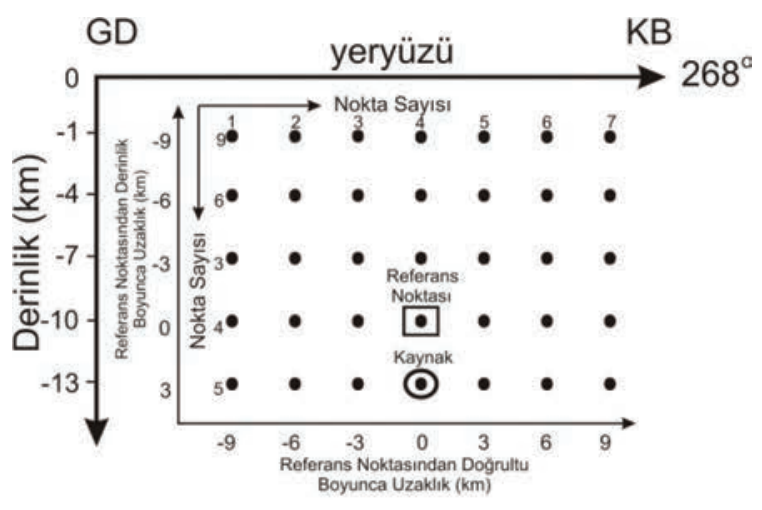

B

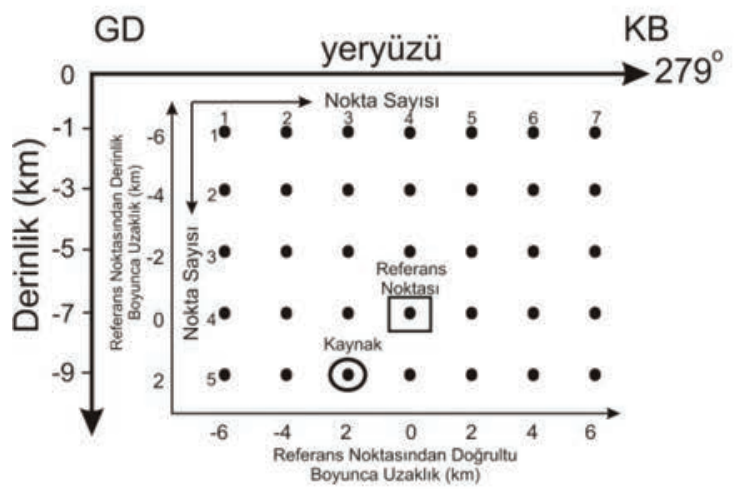

C

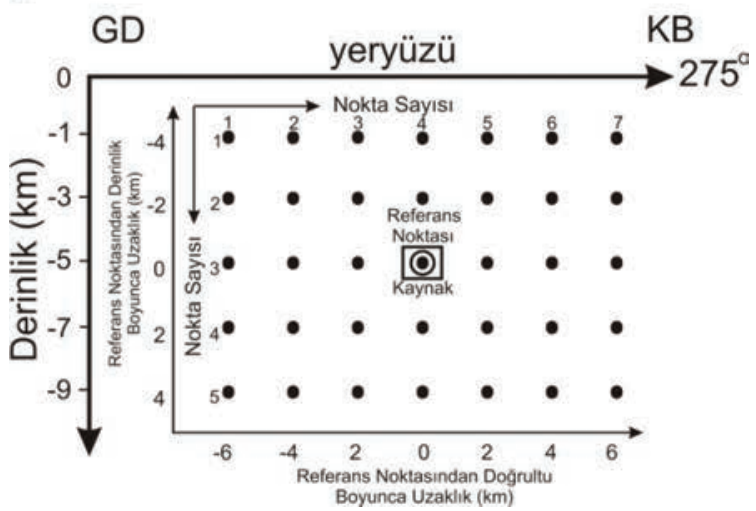

Șekil 7. Nokta-kaynak ters çözümünde (a) 23 Ekim, (b) 25 Ekim ve (c) 9 Kasım 2011 artçı depremleri için kullanılan nokta kaynak gridleri.

Figure 7. Point source grid schemes used for (a) the 23 October, (b) the 25 October and (c) the 9 November 2011 aftershocks in the point source inversion.

orta asal gerilme $(\sigma 2)$ ve en küçük asal gerilme $(\sigma 3)$ eksenleri ile gerilme büyüklüğü oranı (R) olarak bilinen ve $R=(\sigma 2-\sigma 1) /(\sigma 3-\sigma 1)$ șeklinde tanımlanan 4 parametreyi belirlemektedir. Bu 4 parametrenin değișen değerleri farklı gerilme modellerini ifade etmekte olup kullanılan gözlenmiș veri setinin tümüne birden en iyi uyumu veren model gerilme tensör analizinin sonucu olarak çalıșma alanının gerilme rejimini en iyi tanımlayan modeli olarak ele alınır. En iyi uyum veren model bu 4 model parametresinin sistematik olarak değerlerinin geniș bir olasılık aralığında her ters çözüm yinelemesinde bir kez değiștirilmesiyle yapılan grid noktası taraması yoluyla bulunur (Gephart 1990; Pınar vd., 2007). Her yineleme sonucunda kullanılan veri ile hesaplanan gerilme tensörü arasındaki uyumsuzluk, verinin tanımladığı kayma vektörü ile gerilme modelinin tanımladığı kayma vektörü arasındaki en küçük rotasyon açısıdır.

Anderson faylanma teorisi dikkate alındığında, gerilme tensörü analizi sonucunda $\sigma 1(P)$ ve $\sigma$ $3(T)$ yatay ve $\sigma 2(B)$ düșey düzlemde belirlenmișse faylanma doğrultu atımlı, $\sigma 2$ ve $\sigma 3$ yatay düzlemde ve $\sigma 1$ düșey düzlemde belirlenmișse faylanma normal ve $\sigma 1$ ve $\sigma 2$ yatay düzlemde ve $\sigma 3$ düșey düzlemde belirlenmișse faylanma ters atımlı bir faylanmadır (Twiss ve Moores 1992). Gerilme tensörü analizi sonucunda $R=0$ olarak hesaplanmıșsa açılma yani normal faylanmalı, $R=0.5$ olarak hesaplanmıșsa doğrultu atım faylanmalı ve $R=1$ olarak hesaplanmıșsa sıkıșma yani ters faylanmalı bir gerilme rejimi söz konusudur. $\mathrm{R}=0-0.5$ aralığında bulunmușsa transtansiyonel ve $R=0.5-1$ aralığında bulunmușsa transpressif bir bölgesel gerilme rejimi söz konusudur.

Tablo 2'de verilen kaynak parametreleri bilinen ana șok depremler ile yapılan gerilme tensörü ters çözümü sonuçları Șekil 11a'da ve bu depremlere ilave olarak Tablo 3'de verilen 2011 Van depremi artçı depremleri mekanizma çözümleri içerilerek yapılan gerilme tensörü ters çözümü sonuçları da Șekil 11b'de verilmiș ve asal gerilme eksenlerinin belirlenen azimut ve dalım açıları ile $R$ değerleri Tablo 6'da listelenmiștir. Görüleceği üzere, gerilme tensörü analizi sonuçları doğrultu atımlı bir gerilme rejimini ima etmektedir.

\section{TARTIȘMA}

Önceki bölümlerde yapılan analizlerin sonuçlarının değerlendirilmesi bağlamında yapılan 

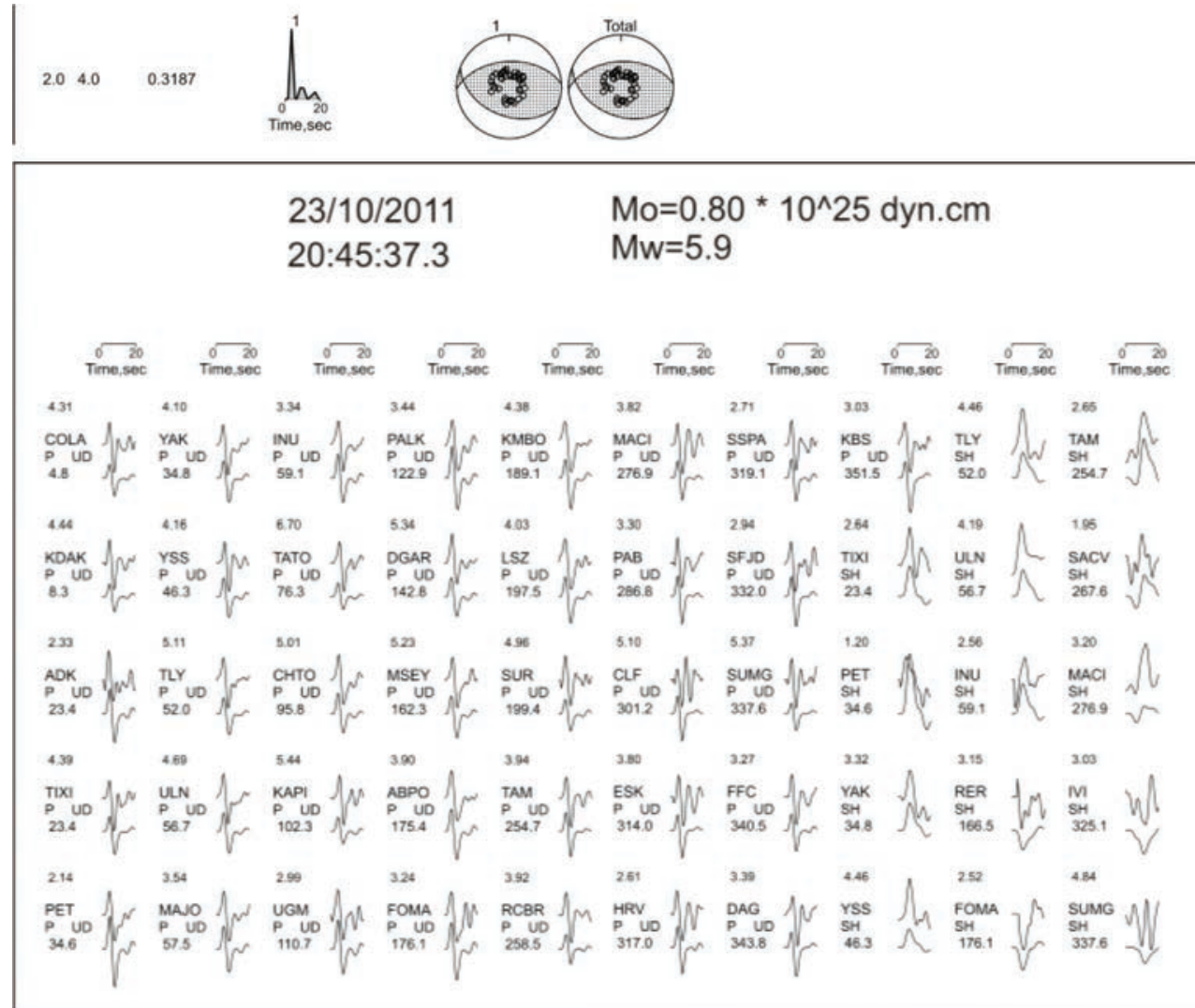

Șekil 8. 23 Ekim 2011 tarihli 2011 Van depremi artçı depremi nokta kaynak analizi sonuçları ve gözlenmiș (üstteki)/yapay dalga șekli karșılaștırması. Her bir dalga șekli solunda istasyon adı, dalga fazı, hangi bileșen kaydı olduğu ve istasyon azimutu bilgileri yer almaktadır.

Figure 8. The point-source analysis results and observed (up)/synthetic (down) waveform pairs for the aftershock of the 2011 Van earthqake occurred on 23 October 2011. Station name, wave phase, component and station azimut information are given in the left of the each waveform pair.

Tablo 6. Van Gölü bölgesi içinde meydana gelmiș depremlerden yapılan gerilme tensörü analizi sonuçları. Analiz sırasında hesaplanan ve sonuçta elde edilen asal gerilme eksenlerinin dağılımları için Sekil 11'e bakınız.

Table 6. Stress tensor analysis results for the earthquakes occurred in the Lake Van Area. Distribution of the principal stress axes estimated during the analysis and resulted from the analysis are shown in Figure 11.

\begin{tabular}{|c|c|c|c|c|c|c|c|c|}
\hline & \multicolumn{2}{|c|}{$\sigma_{1}$} & \multicolumn{2}{c|}{$\sigma_{2}$} & \multicolumn{2}{|c|}{$\sigma_{3}$} & \multirow{2}{*}{ Gerilme rejimi } \\
\cline { 1 - 7 } & $\begin{array}{c}\text { Azimut } \\
\text { (o) }\end{array}$ & $\begin{array}{c}\text { Dalım } \\
\text { (o) }\end{array}$ & $\begin{array}{c}\text { Azimut } \\
\text { (o) }\end{array}$ & $\begin{array}{c}\text { Dalım } \\
\text { (o) }\end{array}$ & $\begin{array}{c}\text { Azimut } \\
\text { (o) }\end{array}$ & $\begin{array}{c}\text { Dalım } \\
\text { (o) }\end{array}$ & R & \\
\hline $\begin{array}{c}\text { Pınar vd., } \\
2007\end{array}$ & 335 & 16 & 255 & 32 & 42 & 53 & 0.8 & Transpressif \\
\hline Bu çalıșma & 169 & 19 & 296 & 61 & 71 & 22 & 0.6 & Doğrultu atımlı \\
\hline Bu çalıșma $^{2}$ & 174 & 19 & 333 & 70 & 82 & 7 & 0.5 & Doğrultu atımlı \\
\hline
\end{tabular}

${ }^{1}$ Tablo 2'de verilen kaynak parametreleri bilinen ana şok depremler ile yapılan gerilme tensörü ters çözümü sonuçları. ${ }^{2}$ Tablo 2'de verilen kaynak parametreleri bilinen ana şok depremlere ilave olarak Tablo 3 'de verilen 2011 Van depremi artçı depremleri mekanizma çözümleri de içerilerek yapılan gerilme tensörü ters çözümü sonuçları 

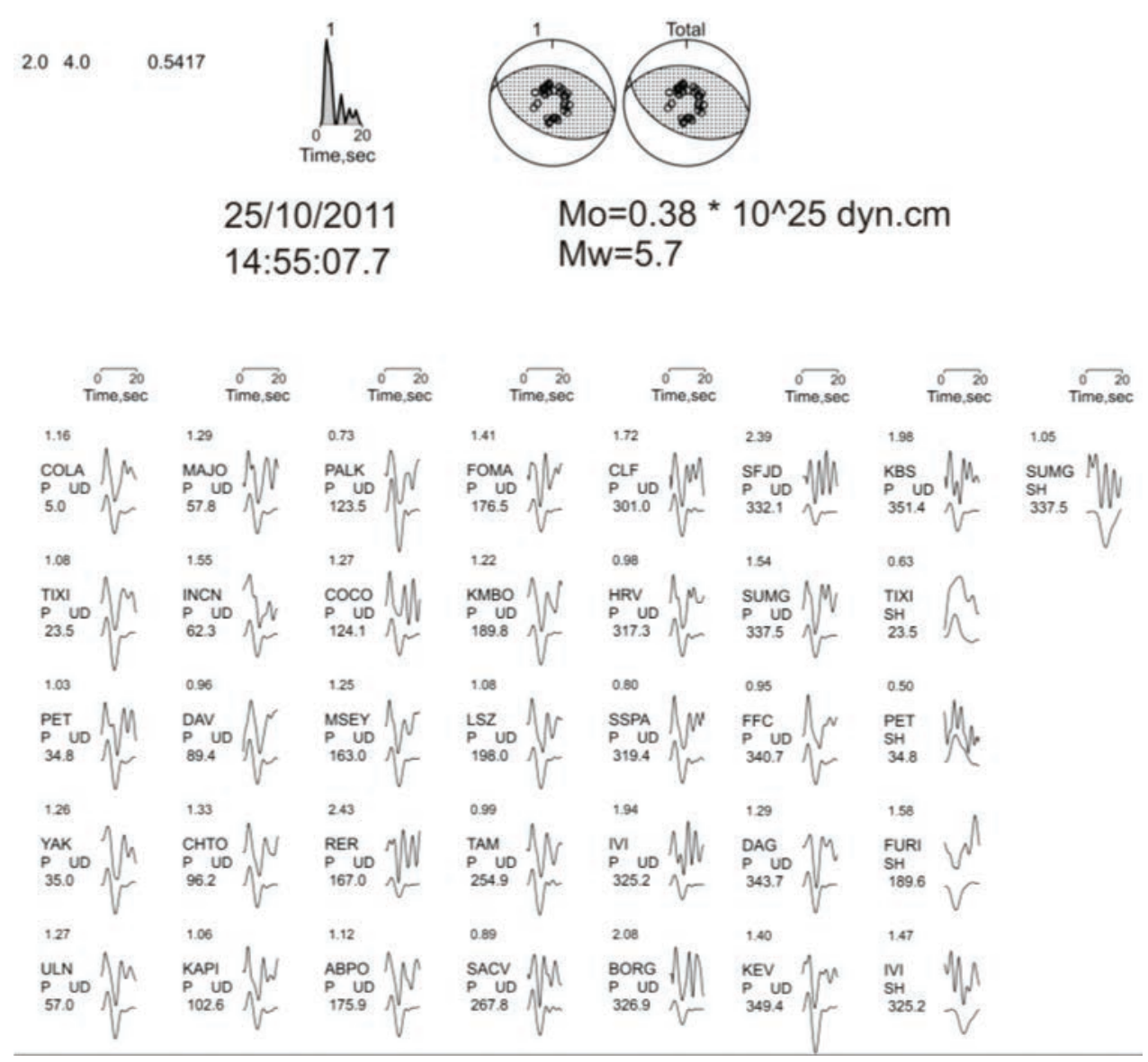

Șekil 9. 25 Ekim 2011 tarihli 2011 Van depremi artçı depremi nokta kaynak analizi sonuçları ve gözlenmiș (üstteki)/yapay dalga șekli karșılaștırması. Her bir dalga șekli solunda istasyon adı, dalga fazı, hangi bileșen kaydı olduğu ve istasyon azimutu bilgileri yer almaktadır.

Figure 9. The point-source analysis results andobserved (up)/synthetic (down) waveform pairs for the aftershock of the 2011 Van earthqake occurred on 25 October 2011. Station name, wave phase, component and station azimut information are given in the left of the each waveform pair.

yorumlar buradaki tartıșmanın kapsamına dahildirler ve anlatımın akıcılığı ve devamılı̆̆ı açısından tamamı bu bölümde içerilmemiștir.

Telesismik sonlu-fay analizi sonuçları 2011 Van depreminin Van fayı üzerinde güneybatıya tek taraflı bir kırıma sonucu oluștuğunu, kayma genliğinin 5 m'yi aștığını, kırımanın genellikle derinde kalıp sığ fay kesimlerine pek ulașmadığını ve önemli kırılmanın yaklașık $25 \mathrm{~km} \times 16$ km'lik bir fay alanını kapsadığını önermektedir. Elliot vd., (2013) InSAR verilerinin modellenmesinden 2011 Van depremi kırılmasının bir çift, basamaklı (en echelon) ve KB'ya doğru farklı eğimleri olan iki fay segmentinden oluștuğunu ve bunlardan doğuda yer alanının üzerinde kaymanın 6 m'ye batıda olanın üzerinde ise 9 m'ye ulaștığını önermișlerdir. Șekil 4'de verilen kayma dağılım modeli her ne kadar iki segmentli bir model fay düzlemi kullanılmadan tek segmentli bir fay modeli kullanılarak elde edilmiș olsa da odağın GB'sında kalan kırıma alanının doğu ve batı yarıları arasındaki kayma genlikleri (doğu yarısı için yaklașık $2.5 \mathrm{~m}$ ve batı yarısı için yaklașı $5.5 \mathrm{~m}$ ) farkı ile bu bulguyu destekler niteliktedir.

Pınar vd., (2007), deprem odak mekanizmalarından Van Gölü bölgesi içinde gerilme rejimini transpressif olarak bulmușlardır. Bu çalıșmada, 

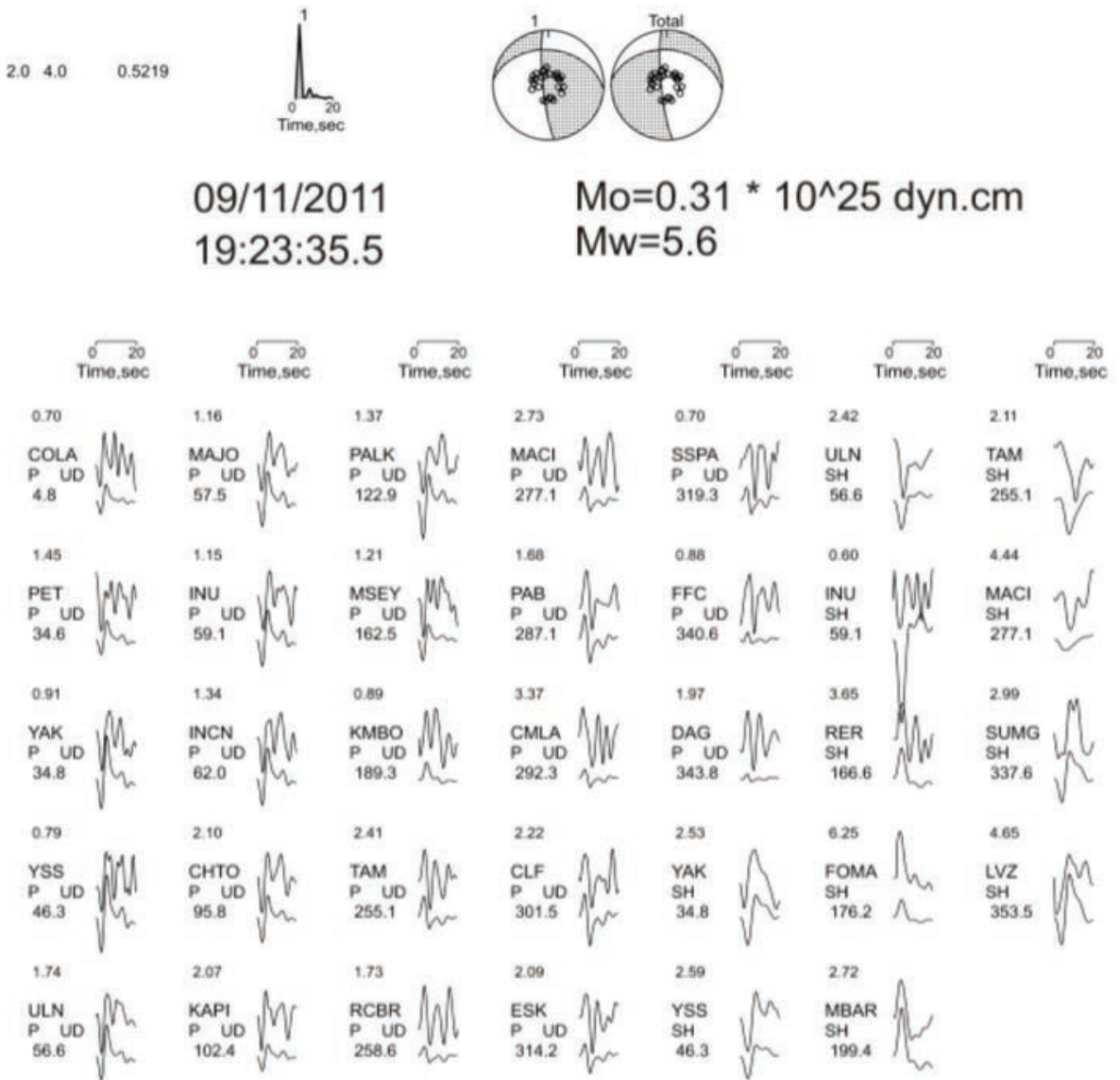

$277.1 \sim$
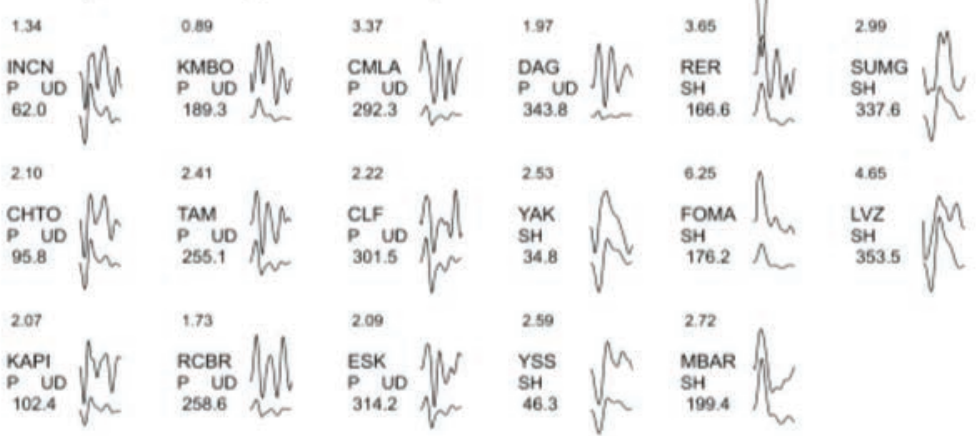

Șekil 10. 9 Kasım 2011 tarihli 2011 Van depremi artçı depremi nokta kaynak analizi sonuçları ve gözlenmiș (üstteki)/yapay dalga șekli karșılaștırması. Her bir dalga șekli solunda istasyon adı, dalga fazı, hangi bileșen kaydı olduğu ve istasyon azimutu bilgileri yer almaktadır.

Figure 10. The point-source analysis results and observed (up)/synthetic (down) waveform pairs for the aftershock of the 2011 Van earthqake occurred on 9 November 2011. Station name, wave phase, component and station azimut information are given in the left of the each waveform pair.

Van Gölü bölgesi için deprem odak mekanizmalarından yapılan bölgesel gerilme tensörü analizi sonucunda gerilme rejimi Tablo 3'de verilen 2011 Van depremi artçı deprem kaynak mekanizmalarının kullanılıp kullanılmamasına bakılmaksızın doğrultu atımlı bir gerilme rejimi bulunmuștur. Bu noktada, bu çalıșmada $\mathrm{PI}$ nar vd., (2007)'den farklı olarak gerilme tensor analizinde 2011 Van depremi ana șok kaynak mekanizması ile Utkucu (2013)'de çözümü yapılmıș iki depremin (Tablo 2'de 1972 Gevaș ve 1976 Van depremleri) odak mekanizmalarının içerildiği hatırlatılmalıdır. Özkaymak (2004), Van Gölü doğusu için arazi verileri fay kinematiği analizinden, Van Gölü doğusu içinde gerilme rejiminin yaklașık K-G doğrultulu bir sıkıșma rejimi olduğunu ifade etmiștir. Tüm bu sonuçlar Van Gölü bölgesi içinde gerilme rejiminin yerel olarak değiștiği ve doğrultu atımlı rejimin baskın olduğu transpressif bir rejimin hâkim olduğu șeklinde yorumlanabilir.

2011 Van depremi, Karadeniz içinde Bartın ili açıklarında meydana gelmiș 3 Eylül 1968 Bartın depremi (Ms=6.6) (Alptekin vd., 1986) istisnası dıșında Türkiye'de aletsel dönemde meydana gelmiș ve odak mekanizması bilinen büyük depremler içinde nerdeyse tamamen ters faylanma sonucu olușmuș ilk depremdir (25 Eylül 1975 Lice depreminin hemen hemen eșit büyüklükte ters ve sol-yanal doğrultu atımlı faylanma bileșenlerine sahip olduğu 


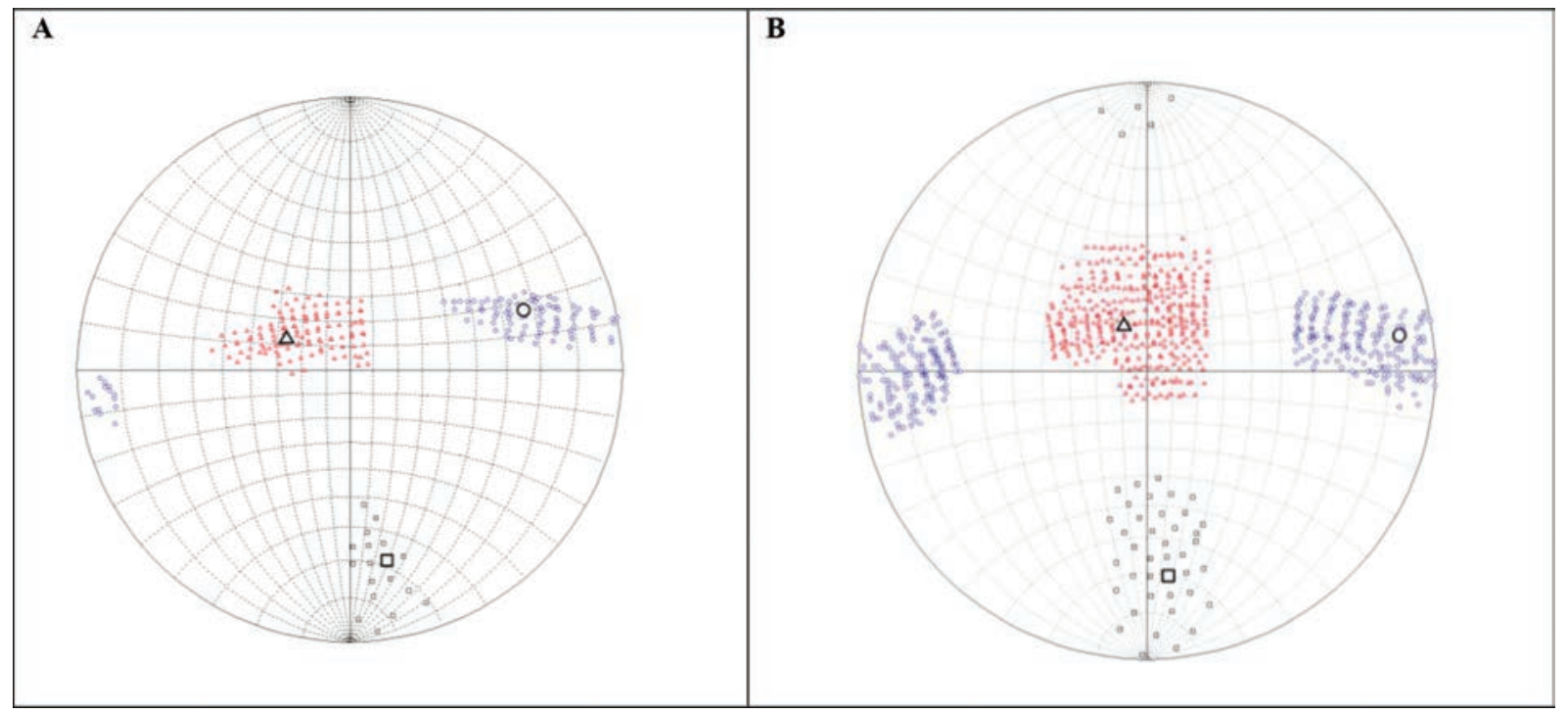

Șekil 11. (a) Tablo 2'de verilen Van Gölü bölgesindeki ana șok depremlerin P ve T eksenlerinden ve (b) ana șok depremler ve Tablo 3'de verilen 23 Ekim 2011 Van depreminin artçılarıyla hesaplanan gerilme tensörü analizi sonuçları. Küçük semboller analiz sırasında hesaplanan asal gerilme eksenlerini gösterirken büyük ve kalın çizgili semboller aynısını en iyi uyumu veren gerilme modeli için vermektedir. Kareler, üçgenler ve çemberler sırasıyla en büyük asal gerilme ekseni $\sigma 1$, orta asalgerilme ekseni $\sigma 2$ ve en küçük asal gerilme ekseni $\sigma 3$ azimut ve dalım açıları çiftlerine ișaret etmektedir. Asal gerilme eksenlerinin azimut ve dalım açıları çiftlerinin ve gerilme büyüklüğü oranı R'nin değerleri için Tablo 6'ya bakınız.

Figure 11. Results of the stress tensor analysis estimated from (a) the $P$-and T-axes of the focal mechanisms of the mainshocks in the Lake Van region given in Table 2 (b) from the mainshocks and the 23 October 2011 Van earthquake's aftershocks given in Table 3. The smaller symbols denote estimated principal stress axes while the large and solid symboles show the same for the best-fitting stress model. The squares, triangles and circles indicate the azimuth and plunges of the maximum compression axis $\sigma 1$, the intermediate stress axis $\sigma 2$ and the minimum stress axis $\sigma 3$, respectively. See Table 6 for the values of the azimuth and plunge pair of the principal stress axes and the stress magnitude ratio $R$.

hatırlatılmalıdır). Bu deprem bölgede yaygın olarak gözlenen doğrultu atımlı faylanmaların yanısıra ters faylanmalarında meydana gelebileceğini kanıtlamıștır.

\section{SONUÇLAR}

23 Ekim 2011 Van depreminin geniș bant uzakalan cisim dalga șekilleri kullanılarak sonlu-fay modellemesi yapılmıș ve kırımanın ters faylanma sonucu oluștuğu ve tek taraflı olarak 25 km'lik bir uzaklık boyunca GB'ya yayıldığı görülmüștür. Kırımanın 5 km'den sığ derinliklere pek yayılmadığı, en büyük kaymanın $5.5 \mathrm{~m}$ civarında olduğu, kırımanın yaklașık 11 sn sürdüğü ve toplamda $4.6 \times 10^{19} \mathrm{Nm}$ 'lik $\left(\mathrm{M}_{\mathrm{w}}=7.1\right)$ bir sismik momentin özelliklede 5-9 sn kırılma zamanı aralığında serbestlendiği belirlenmiștir. Sonlu-fay analizi en büyük kayma alanı için 3 sn'lik bir yükselim zamanı önermiștir. 2011 Van depreminin 3 büyük artçı depreminin uzak-alan nokta kaynak modellemeleri sonucu elde edilen kayak mekanizmaları bu artçı depremlerin sadece ana șok kırılma düzleminde ya da komșu ters faylar üzerinde olușmadığını 9 Kasım 2011 artçı depreminde olduğu gibi komșu doğrultu atımlı faylar üzerinde de artçı depremlerin tetiklendiğine ișaret etmiștir.

Van Gölü bölgesindeki mevcut ana șok deprem odak mekanizmaları kullanılarak ve bunlara 2011 Van depremi artçı depremleri eklenerek gerilme tensör analizleri bölgede gerilme rejiminin doğrultu-atımlı olduğunu ve sıkıșma gerilmesi ekseninin kabaca K-G doğrultusunda uzandığını önermiștir. 


\section{KATKI BELIRTME}

Bu çalısmada kullanılan 29 Ekim 2011 Van depremi artçı deprem lokasyonları Kandilli Rasathanesi ve Deprem Arastırma Enstitüsü Tarafından saglanmıstır.

Yazarlar, lokasyon verilerini saglayan Dr. Dogan KALAFAT'a tesekkür ederler.

"Bu çalısma Sakarya Üniversitesi Bilimsel Arastırma Projeleri Komisyonu tarafından desteklenmistir." Proje Numarası: 2012-01-14-005)

\section{REFERANSLAR}

AFAD (2011). Van depremi (23 Ekim 2011) raporu. T.C. Bașbakanlık Afet ve Acil Durum Yönetimi Bașkanlığı, Deprem Dairesi Bașkanlığı, Ankara. 100 pp.

Akyüz S, Zabcı C, Sançar T ., 2011. 23 Ekim 2011 Van depremi hakkında ön rapor. İstanbul Teknik Üniversitesi, İstanbul, Kasım 2011, 19 pp (in Turkish).

Albini, P., Demircioglu, M. B., Locati, M., Rovida, A., Sesetyan, K., Stucchi, M., and Vigano, D.: In search of the predecessors of the 2011 Van (Turkey) Earthquake, Seismol. Res. Lett., 83, 855-862, doi:10.1785/0220110146, 2012.

Alptekin, Ö., Nabelek, J.L. ve Toksöz, M.N., 1986. Source Mechanism of the Bartın earthquake of September 3, 1968 in Northwestern Turkey: evidence for active thrust faulting at the southern Black Sea margin, Tectonophysics, 122, 7388.

Ambraseys, N. N, Finkel, C., 1995. The seismicity of Turkey ve adjacent areas: a historical review, 1500-1800. Eren Publication, İstanbul, ISBN 975-7622-38-9, $240 \mathrm{pp}$.

Ambraseys, N. N., 1988. Engineering seismology. Earthquake Eng Struc 17:1-105.

Ambraseys, N. N, Adams R. D., 1989. Longterm seismicity of North Armenia. Eos. Transactions, American Geophysical Union, 70:145-154.

Ambraseys, N. N., 1989. Temporary seismic quiescence: SE Turkey. Geophys J 96:311-331.
Ambraseys, N., 2009. Earthquakes in the Mediterranean ve Middle East: a multidisciplinary study of seismicity up to 1900 . Cambridge University Press. 947pp. ISBN 978-0-521-87292-8.

Atzori, S, Tolomei, C., Salvi, S. Zoffoli, S. , 2011. Coseismic ground displacement ve preliminary source models for the 10/23/2011, $M W=7.2$, Van earthquake, Eastern Turkey. Available from URL: http://www.sigris.it/images/stories/ SIGRIS-4-Van_1stRep.pdf

Barka, A., Kadinsky-Cade K., 1988. Strike-slip fault geometry in Turkey ve its influence on earthquake activity. Tectonics 7:663-684.

CEDIM, 2011. Comparing the current impact of the Van Earthquake to past earthquakes in Eastern Turkey. Center for Disaster Management ve Risk Reduction Technology (CEDIM) Forensic Earthquake Analysis Group, Report 4, November 2011, 28 pp.

Çelebi, E., Çağlar, N., Özocak, A., Aktaș, M., Kutanis, M., Mert, N., Özcan, Z., Kırtel, O., 2011. 23 Ekim 2011 Van-Erciș depremi değerlendirme raporu. Sakarya Üniversitesi Mühendislik Fakültesi İnșaat Mühendisliği Bölümü, Sakarya, 58 pp (in Turkish).

Degens, E. T, Wong, H. K., Kurtman, F., Finkch, P., 1978. Geological development of Lake Van. in: The Geology Lake Van. MTA Press, No. 169:134-146.

Dhont, D., Chorowicz, J., 2006. Review of the neotectonics of the Eastern Turkish-Armenian Plateau by geomorphic analysis of digital elevation model imagery. Int $J$ Earth Sci (Geol Rundsch) 95:34-49. doi:10.1007/s00531-005-0020-3.

Djamour, Y., Vernant, P., Nankali, H. R., Tavakoli , F., 2011. NW Iran-eastern Turkey present-day kinematics: Results from the Iranian permanent GPS network Earth ve Planetary Science Letters , 307,27-34 doi:10.1016/j. epsl.2011.04.029.

Elliott, J.R. Copley, A. C. , Holley, R., Scharer,K. ve Parsons, B., 2013. The 2011 Mw 
7.1 Van (Eastern Turkey) earthquake Journal Of Geophysical Research: Solid Earth, Vol. 118, 1-19, doi:10.1002/ jgrb.50117.

Emre, Ö., Duman, T. Y., Özalp, S., Elmacı, H., 2011. 23 Ekim 2011 Van depremi saha gözlemleri ve kaynak faya ilișkin ön değerlendirmeler. MTA Jeoloji Etütler Dairesi, Ankara, $22 \mathrm{pp}$ (in Turkish).

Eyidoğan, H., Güçlü, U., Utku Z, Değirmenci, E., 1991. Macroseismic guide for large Turkey earthquakes 1900-1988. İstanbul Technical University, Faculty of Mine, Department of Geophysics, İstanbul, $198 \mathrm{pp}$ (in Turkish).

Hartzell, S. H, Heaton, T. H., 1983. Inversion of strong-ground motion ve teleseismic wave form data for the fault rupture history of the 1979 Imperial Valley, California, earthquake. Bull Seismol. Soc. Am. 73:1553-1583.

Hayes, G., 2011. Updated Result of the Oct 23, $2011 \mathrm{Mw} 7.1$ Eastern Turkey Earthquake available from URL: http://earthquake.usgs.gov/earthquakes/eqinthenews/2011/ usb0006bqc/finite_ fault. php.

Jackson, J., 1992. Partitioning of strike-slip ve convergent motion between Eurasia ve Arabia in Eastern Turkey ve the Caucasus, J Geophys Res 97:12471-12479.

Jackson, J., McKenzie, D. P., 1984. Active tectonics of the Alpine-Himalayan belt between western Turkey ve Pakistan. Geophys J R Astr Soc 77:185-264.

Jeffreys, H ., ve K. E. Bullen, 1958. Seismological Tables, Office of the British Association, Burlington $\mathrm{H}$ ouse, London.

JMO (2011). Van (Tabanlı-Edremit) depremleri raporu. Jeoloji Mühendisleri Odası Raporu, Ankara. $52 \mathrm{pp}$ (in Turkish).

Kalafat, D., 1995. 1964-1994 yılları arasında Türkiye ve yakın çevresinde etkili olmuș depremlerin makrosismik gözlemleri. Deprem Araștırma Bülteni 73:60-97 (in Turkish).

Kalafat, D., 1998. Anadolu'nun tektonik yapılarının deprem mekanizmaları açısından irdelenmesi. Deprem Araștırma Bülteni 77:1-277 (in Turkish).

Kalafat, D., Güneș, Y., Kara, M., Deniz, P., Kekovalı, K., Kuleli, S. H, Gülen, L., Yılmazer M, Özel, N., 2007. A revised ve extended earthquake catalogue for Turkey since 1900( $M \geq 4.0$ ). Boğaziçi University, Kandilli Rasathanesi ve Deprem Araștırma Enstitüsü, Bebek-İstanbul, 553 pp (in Turkish).

Kikuchi, M. ve H. Kanamori, 1991. Inversion of complex body wave-III, Bull. Seism. Soc. Am., 81, 2335-2350.

Koçyiğit A, Yılmaz A, Adamia S, Kuloshvili, S., 2001. Neotectonics of East Anatolia plateau (Turkey) ve lesser Caucasus: implication for transition from thrusting to strike-slip faulting. Geodinamica Acta, 14:177-195.

Koçyiğit, A. and Altıner, D., Tectonostratigraphic Evolution of the North Anatolian Palaeorift (NAPR): Hettangian-Aptian Passive Continental Margin of the Northern Neo-Tethys, Turkey. Turkish Journal of Earth Sciences, 11, (2002), p.1-27

Lahn, E., 1946. A note about earthquakes in Van area (July-November 1945). Maden Tetkik ve Arama ve Enstitüsü 1(35):126132 (in Turkish and French).

Lahn, E., 1949. Seismological investigations in Turkey. Bull Seismol Soc Am 39:67-71.

Langston, C. A, Helmberger, D. V., 1975. A procedure for modelling shallow dislocation sources. Geophys J R astr Soc 42:117-130.

Lawson, C.L., Hanson, R.J., 1974. Solving Least Square Problem. Prentice-Hall, New Jersey, $339 \mathrm{pp}$.

Litt, T., Krastel, S., Sturm, M., Kipfer, R., Örçen, S., Heumann, G., Franz, S. O., Ulgen, U. B, Niessen, F., 2009. 'PALEOVAN', International Continental Scientific Drilling Program (ICDP): site survey results ve perspectives. Quaternary Sci Rev 28:1555-1567. doi:10.1016/j.quascirev.

McClusky, S., Balassanian, S., Barka, A., Demir, C., Ergintav, S., Georgiev, I., Gürkan O, Hamburger, M., Hurst, K., Kahle, H., 
Kastens, K., Nadariya, M., Ouzouni, A., Paradissis, D., Peter, Y., Prilepin, M., Reilinger, R., Sanli, I., Seeger, H., Tealeb, A., Toksöz, M. N., Veis, G., 2000. GPS constraints on plate kinematics ve dynamics in the Eastern Mediterranean ve Caucasus. J Geophys Res 105:5695-5719.

McKenzie, D. P., 1972. Active tectonics of the Mediterranean region. Geophys JR astr Soc 30: 109-185.

METU/EERC (2011) 23 Ekim 2011 Mw 7.2 Van depremi sismik ve yapısal hasara ilișkin saha gözlemleri. Report No: 2011-04, Kasım 2011, Ankara, 76 pp.

MTA, Türkiye Yenilenmiș Diri Fay Haritası, available at: http://www.mta.gov.tr/v2.0/ default.php?id=yeni diri fay haritalarigoruntule (last access: 19 June 2013), 2012.

Özkaymak, Ç., Yürür, T., Köse, O., 2004. An example of intercontinental active collisional tectonics in the Eastern Mediterranean region (Van, eastern Turkey). $5^{\text {th }}$ International Symposium on Eastern Mediterranean Geology, 14-20 April 2004, Thessaloniki, Greece, Proceedings Book, pp 591-593.

Pınar, A., 1995. Rupture process ve spectra of some major Turkish earthquakes ve their seismotectonic implications. Dissertation, Boğaziçi University, İstanbul.

Pınar, A., Honkura, Y., Kuge, K., Matsushima, M., Sezgin, N., Yılmazer, M., Öğütçü, Z., 2007. Source mechanism of the 2000 November 15 Lake Van earthquake $(M w=5.6)$ in eastern Turkey ve its seismotectonic implications. Geophys J Int 170(2):749-763, doi: 10.1111/j.1365246X.2007.03445.x

Reilinger, R., McClusky, S., Vernant, P., Lawrence, S., Ergintav, S., Cakmak, R., Özener, H., Kadirov, F., Guliev, I., Stepanyan, R., Nadariya, M., Hahubia, G., Mahmoud, S., Sakr, K., ArRajehi, A., Paradissis, D., Al-Aydrus, A., Prilepin, M., Guseva, T., Evren, E., Dmitrotsa, A., Filikov, S,V, Gomez, F., Al-Ghazzi, R., Karam, G., 2006. GPS constraints on continental deformation in the Africa-Arabia-Eurasia continental collision zone ve implications for the dynamics of plate interactions. J Geophys Res 111, B05411, doi:10.1029/2005JB004051.

Sandvol, E., Türkelli, N., Barazangi, M., 2003. The Eastern Turkey Seismic Experiment: The study of a young continent-continent collision: An example from eastern Turkey. Geophys Res Lett 30(24), 8038, doi:10.1029/2003GL018912, 2003.

Sinclair, T., 1999. Two problems concerning the Van Region: Arakel of Tabriz on the earthquake of 1646 ve evidence for the rise in the level of the lake. In: Zachariadou E, (ed.), Natural Disasters in the Ottoman Empire, Crete University Press, pp 207-222.

Stewart, G. S., Kanamori, H., 1982. Complexity of rupture in large strike-slip earthquakes in Turkey. Phys Earth Planet Inter 28: 70-84.

Șaroğlu, F., Emre, Ö., Kușçu, i., 1992. Active fault map of Turkey. Publ Miner Res ExpIor Ins. Turk, Ankara, Turkey.

Șengör, A. M. C, Görür, N., Șaroğlu, F., 1985. Strike-slip faulting ve related basin formation in zones of tectonic escape: Turkey as a case study. In Strike-slip faulting ve basin formation, eds. Biddle KT ve Christie-Blick N, Spec Publ Soc Econ Paleontol Mineral 37-227-264.

Șengör, A. M. C, Özeren, S., Genç, T., Zor, E., 2003. East Anatolian high plateau as a mantle-supported, northsouth shortened domal structure. Geophys Res Lett 30(24), 8045, doi:10.1029/2003GL017858, 2003.

Tașman, C.E., 1946. Varto ve Van earthquakes. Publ Miner Res Explor Ins Turk, 2(36):287-291 (in Turkish).

Taymaz, T., Eyidoğan, H., Jackson, J., 1991. Source parameters of large earthquakes in the East Anatolian fault zone (Turkey). Geophys J Int 106:537-550.

Toksöz, M. N., Nabelek, J., Arpat, E., 1978. Source properties of the 1976 earthquake in eastern Turkey: a comparison of field 
data ve teleseismic results, Tectonophysics, 49:199-205.

Twiss, R. J. and Moores, E.M., 1992. Structural Geology, W.H. Freeman ve Co., New York, sf. 203.

Utkucu, M., 2013. 23 October 2011, Van, Eastern Anatolia, earthquake $(\mathrm{Mw}=7.1)$ and seismotectonics of Lake Van area. J. Seismol., 17, 783-805, doi: 10.1007/ s10950-012-9354-z.

Vernant P, Nilforoushan, F., Hatzfeld, D., Abbasi, M. R., Vigny, C., Masson, F., Nankali, H., Martino, J., Ashtiani, A., Bayer, R., Tavakoli, F., Chery, J., 2004. Presentday crustal deformation ve plate kinematics in the Middle East constrained by GPS measurements in Iran ve northern Oman. Geophys J Int 157:381-398.

Wald, D. J., Heaton, H. T., 1994. Spatial ve temporal distribution of slip for the 1992 Lveers, California, earthquake, Bull Seismol Soc Am 84:668-691.

Wong, H.K., Degens, E.T., 1978. The bathymetry of Lake Van, eastern Turkey. In The Geology Lake Van, pp. 6-10. eds. Degens ET ve Kurtman F, M.T.A. Press, No. 169, Ankara, Turkey. 